\title{
Sedimentary ancient DNA and pollen reveal the composition of plant organic matter in Late Quaternary permafrost sediments of the Buor Khaya Peninsula (north-eastern Siberia)
}

\author{
Heike Hildegard Zimmermann ${ }^{1,2}$, Elena Raschke ${ }^{1,3}$, Laura Saskia Epp ${ }^{1}$, Kathleen Rosmarie Stoof-Leichsenring ${ }^{1}$, \\ Georg Schwamborn ${ }^{1}$, Lutz Schirrmeister ${ }^{1}$, Pier Paul Overduin ${ }^{1}$, and Ulrike Herzschuh ${ }^{1,2}$ \\ ${ }^{1}$ Alfred Wegener Institute Helmholtz Centre for Polar and Marine Research, Periglacial Research Unit, Telegrafenberg A43, \\ 14473 Potsdam, Germany \\ ${ }^{2}$ Institute of Earth and Environmental Sciences, University of Potsdam, Karl-Liebknecht-Str. 24-25, \\ 14476 Potsdam-Golm, Germany \\ ${ }^{3}$ Arctic and Antarctic Research Institute, Bering St. 38, 199397 St. Petersburg, Russia
}

Correspondence to: Heike Hildegard Zimmermann (heike.zimmermann@awi.de)

and Ulrike Herzschuh (ulrike.herzschuh@awi.de)

Received: 9 September 2016 - Discussion started: 27 September 2016

Revised: 26 December 2016 - Accepted: 11 January 2017 - Published: 7 February 2017

\begin{abstract}
Organic matter deposited in ancient, ice-rich permafrost sediments is vulnerable to climate change and may contribute to the future release of greenhouse gases; it is thus important to get a better characterization of the plant organic matter within such sediments. From a Late Quaternary permafrost sediment core from the Buor Khaya Peninsula, we analysed plant-derived sedimentary ancient DNA (sedaDNA) to identify the taxonomic composition of plant organic matter, and undertook palynological analysis to assess the environmental conditions during deposition. Using sedaDNA, we identified 154 taxa and from pollen and nonpollen palynomorphs we identified 83 taxa. In the deposits dated between 54 and $51 \mathrm{kyr} \mathrm{BP}$, sedaDNA records a diverse low-centred polygon plant community including recurring aquatic pond vegetation while from the pollen record we infer terrestrial open-land vegetation with relatively dry environmental conditions at a regional scale. A fluctuating dominance of either terrestrial or swamp and aquatic taxa in both proxies allowed the local hydrological development of the polygon to be traced. In deposits dated between 11.4 and 9.7 kyr BP (13.4-11.1 cal kyr BP), sedaDNA shows a taxonomic turnover to moist shrub tundra and a lower taxonomic richness compared to the older samples. Pollen also records a shrub tundra community, mostly seen as changes in relative proportions of the most dominant taxa, while a
\end{abstract}

decrease in taxonomic richness was less pronounced compared to sedaDNA. Our results show the advantages of using sedaDNA in combination with palynological analyses when macrofossils are rarely preserved. The high resolution of the sedaDNA record provides a detailed picture of the taxonomic composition of plant-derived organic matter throughout the core, and palynological analyses prove valuable by allowing for inferences of regional environmental conditions.

\section{Introduction}

Decomposition of soil organic carbon from ancient permafrost deposits may augment ongoing global warming, but how intensely will depend on the character of the organic matter. Most soil organic carbon in permafrost was deposited during the Late Pleistocene and Holocene (cf. Schirrmeister et al., 2011a). Throughout the last glacial (Marine Isotope Stages 4 to 2, ca. 71-10.5 kyr BP), much of north-eastern Siberia was non-glaciated (Hubberten et al., 2004). The region was exposed to extremely cold conditions, which resulted in the formation of deep permafrost with an estimated thickness of $500 \mathrm{~m}$ (Duchkov et al., 2014) and in lowlands of polygonal tundra environments. Ice-wedge polygons developed after many cycles of wintertime frost cracking and sub- 
sequent springtime meltwater infiltration into these cracks. Ice wedges create ridges surrounding polygonal depressions (e.g. Lachenbruch, 1962; Leffingwell, 1915; Minke et al., 2007). The cold and water-saturated conditions in the depressions caused the accumulation of organic matter in soil horizons, as decomposition rates were low (Davidson and Janssens, 2006; Hugelius et al., 2014). Over time, ice- and organic-matter-rich permafrost was formed (Schirrmeister et al., 2011b). These Late Pleistocene deposits are called Ice Complex or Yedoma and are estimated to store $83 \pm 12 \mathrm{Pg}$ organic carbon (Hugelius et al., 2014), which accounts for more than $10 \%$ of the total organic carbon pool in permafrost globally.

Permafrost is susceptible to future climate-changeinduced increases in ground temperatures, which can lead to active layer deepening (Romanovsky et al., 2010) and thermoerosion (Grosse et al., 2011). When permafrost sections thaw, microbial-driven decomposition rates increase and release climate-relevant greenhouse gases that further enhance climate warming in a positive feedback loop (Knoblauch et al., 2013; Wagner et al., 2007). To improve assessments of the potential greenhouse gas release from organic matter, knowledge about its composition is of great relevance as it allows for the inference of organic matter decomposability (Cornwell et al., 2008; Hobbie, 1992). Furthermore, knowledge about the conditions under which the organic matter accumulated in the past can help us understand how it accumulates today (Lyell, 1830). Recently, the sediments, cryolithology and stratigraphy of outcrops on the western coast of the Buor Khaya Peninsula in north-eastern Siberia were described, including organic carbon quantity, quality and degradability (Günther et al., 2013b; Schirrmeister et al., 2016; Stapel et al., 2016; Strauss et al., 2012, 2013, 2015). However, the palaeobotany of the site has not been studied. It represents a more southerly example of highly degraded Ice Complex in the central Laptev region between the Lena Delta to the west and the Indigirka lowlands to the east. The closest palaeobotanical reconstruction was carried out at the north-eastern coast of the peninsula using palaeolake sediments, but only of Mid-Holocene origin (Willerslev et al., 2014). Hence a record which describes the floristic composition of organic matter from the last glacial period is needed to complete our understanding of the source and quality of organic carbon in these deposits.

Plant macrofossils and/or pollen are the palaeobotanical records usually used to study the permafrost soil organicmatter composition and environmental conditions during its deposition. Plant macrofossils, which can often be identified to species level, mostly originate directly from former vegetation at the study site, allowing past local environmental conditions to be inferred (Birks, 2001). However, identifiable macrofossils are usually preserved in low quantities and preservation varies strongly among taxa, which hinders a quantitative exploitation of this proxy data (Kienast et al., 2001). Pollen, in contrast, is preserved in sufficient amounts to quantify its composition, but in arctic treeless ecosystems it originates from across a variable extent from extra-local to local sources (Birks, 2001; van der Knaap, 1987) and taxonomic resolution is mostly limited to genusand family level (Beug, 2004; Moore et al., 1991). A comparatively new proxy is the analysis of sedimentary ancient DNA (sedaDNA), which originates from disseminated material within sediments (Haile et al., 2009; Rawlence et al., 2014). Its application to permafrost sediments was introduced by Willerslev et al. (2003) who reported the successful retrieval of plant DNA as old as 300000 to 400000 years. Since then, several studies prove that DNA is exceptionally well preserved in permafrost sedimentary archives with respect to vascular plants (Willerslev et al., 2003), bryophytes (Epp et al., 2012), fungi (Bellemain et al., 2013; Epp et al., 2012; Lydolph et al., 2005), bacteria (e.g. Wagner et al., 2007; Willerslev et al., 2004b), invertebrates (Epp et al., 2012), birds (Epp et al., 2012), and mammals (e.g. Arnold et al., 2011; Haile et al., 2009; Willerslev et al., 2003, 2014). The constantly cool temperatures of permafrost lead to reduced microbial and enzymatic degradation (Levy-Booth et al., 2007) and limited hydrolytic damage, since up to $97 \%$ of the water is frozen (Willerslev et al., 2003, 2004a). SedaDNA is supposed to be of local origin (Boessenkool et al., 2014; Haile et al., 2007; Jørgensen et al., 2012; Parducci et al., 2013; Pedersen et al., 2016; Sjögren et al., 2016) and can be preserved extracellularly, even when macrofossil evidence is absent (Arnold et al., 2011; Willerslev et al., 2003). In comparison to arctic pollen and macrofossils, the taxonomic resolution of sedaDNA exceeds that of pollen in almost all groups of higher plants and is close to the resolution of macrofossils (Jørgensen et al., 2012; Pedersen et al., 2013; Sønstebø et al., 2010).

The purpose of this study is to combine sedaDNA and pollen analyses to reconstruct past local and regional flora from a Late Quaternary permafrost sediment core, which was recovered from the western coast of the Buor Khaya Peninsula, a sparsely investigated region of the Late Pleistocene Ice Complex. The sediments contain moderate organic carbon content of generally 2-5\% (Schirrmeister et al., 2016; Stapel et al., 2016; Strauss et al., 2015). Given that organic matter is the substrate for microbial turnover and the future release of greenhouse gases, it is crucial to get a better characterization of the plant organic matter within those sediments. At the same time it is necessary to understand the environmental conditions that prevailed when the organic matter was deposited, to allow for inferences of modern and future processes under comparable environmental conditions. We therefore aim to answer the following questions: (1) what is the taxonomic composition of plant organic matter stored locally in the ancient permafrost sediments? (2) What were the environmental conditions during the time of organic matter accumulation? 


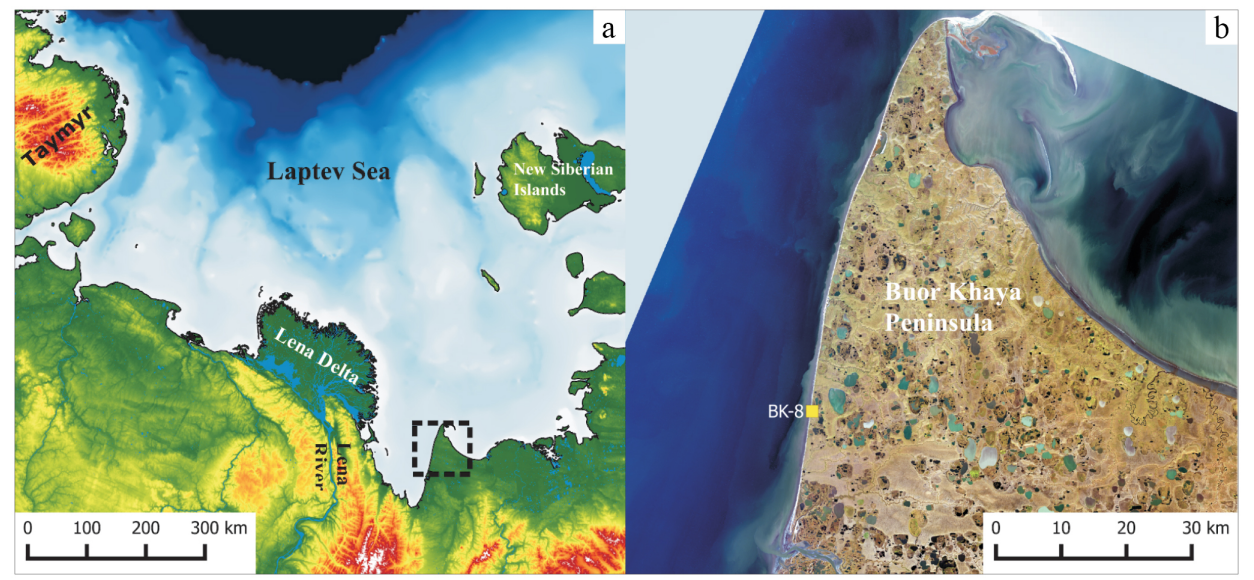

Figure 1. (a) Geographical setting of the study site in the southern Laptev Sea with the Buor Khaya Peninsula framed by dashed lines and (b) the position of the BK-8 drilling site on the western coast of the peninsula (compiled by Bennet Juhls).

\section{Geographical settings}

The Buor Khaya Peninsula belongs to the north-eastern Siberian Yana-Indigirka lowlands and is surrounded by the Buor Khaya Bay and the Yana Bay in the southern Laptev Sea (Fig. 1). It is underlain by continuous permafrost with ground temperatures of less than $-10^{\circ} \mathrm{C}$ (Schirrmeister et al., 2016). The study area has a subarctic continental climate with a short growing season and long severe winters. Mean annual precipitation is $321.5 \mathrm{~mm}$, and the mean annual air temperature is $-12.8^{\circ} \mathrm{C}$ (mean temperature of the warmest month: $8.7^{\circ} \mathrm{C}$, mean temperature of the coldest month: $-32.5^{\circ} \mathrm{C}$ ) at the closest meteorological station in Tiksi (WMO 218240) based on data between 1981 and 2010.

The treeless landscape is covered by polygonal tundra and a mosaic of thermokarst and alas depressions and Yedoma "hills" up to $37 \mathrm{~m}$ a.s.l. (Günther et al., 2013a). Thermokarst depressions formed by permafrost thaw and ground subsidence as a consequence of increasing temperatures after the Last Glacial Maximum (Czudek and Demek, 1970), whereas Yedoma hills and uplands are relicts of Late Pleistocene accumulation plains (Schirrmeister et al., 2013). According to the Circumpolar Arctic Vegetation Map (CAVM Team, 2003) the modern vegetation cover can be classified mostly as erect dwarf-shrub tundra, in places as tussock-sedge, dwarf-shrub, and moss tundra, and in the northernmost part of the peninsula as sedge, moss, and dwarf-shrub wetlands. On raised microsites, such as ridges of low-centred icewedge polygons, sedge, moss, dwarf-shrub wetlands also include components of non-tussock sedge, dwarf-shrub, moss tundra.

\section{Material and methods}

\subsection{Core material}

In April 2012, an $18.9 \mathrm{~m}$ long core with frozen sediment (BK-8) was drilled from the top of an eroding Yedoma hill at $34 \mathrm{~m}$ a.s.l. (Fig. 1), located at about $100 \mathrm{~m}$ from the cliff edge on the western coast of the Buor Khaya Peninsula $\left(71.420^{\circ} \mathrm{N}, 132.111^{\circ} \mathrm{E}\right)$. Detailed descriptions of the fieldwork and cryolithological properties (i.e. ground ice and sediment features) are published in Günther et al. (2013a) and Schirrmeister et al. (2016). Radiocarbon dating was performed on bulk plant macro remains by accelerator mass spectrometry at the CologneAMS laboratory, Germany (Schirrmeister et al., 2016) and radiocarbon ages are given in Table 1. Based on field observations, core descriptions and analytical datasets, Schirrmeister et al. (2016) subdivided the core into six cryolithological units (Table 1). Absolute icecontents varied between 66 and $84 \mathrm{wt} \%$, which is typical for Yedoma (Schirrmeister et al., 2011b, 2016). Plant remains were sparsely distributed throughout the core and were composed mainly of fine rootlets, grass fragments, small woody pieces and very few seeds and fruits.

\subsection{Subsampling of the permafrost core}

In January 2014 the core segments were cut into two halves. One was stored as an archive and the second was subsampled. The opening of the core and the subsampling took place at the German Research Centre for Geosciences Helmholtz Centre Potsdam in the climate chamber at a temperature of $-10^{\circ} \mathrm{C}$, where no genetic experiments were performed either before or after. The drilling mud was removed using a band saw. Approximately $3 \mathrm{~mm}$ of the surface was removed with a clean straight draw knife of $225 \mathrm{~mm}$ length (Wilh. Schmitt \& Comp. GmbH \& Co. KG, Germany). Before use, the draw knife was cleaned with $5 \%$ Deconex- 
Table 1. Cryolithological units from the bottom to the top with sample depths below surface (m), radiocarbon ages given as years before present (yr BP), calibrated radiocarbon ages (cal yr BP) and characteristics according to Schirrmeister et al. (2016).

\begin{tabular}{|c|c|c|c|c|c|}
\hline Unit & Depth (m) & $\begin{array}{r}\text { Radiocarbon ages } \\
(\mathrm{yr} \mathrm{BP})\end{array}$ & $\pm(\mathrm{yr})$ & $\begin{array}{l}\text { Calibrated ages }(2 \sigma) \\
(\text { cal yr BP) }\end{array}$ & Cryolithological characteristics \\
\hline $1(18.9-16.0 \mathrm{~m})$ & 16.13 & 52700 & 800 & not calculable & $\begin{array}{l}\text { horizontally bedded grey-brown, } \\
\text { silty fine-grained sand; electric con- } \\
\text { ductivity up to } 14 \mathrm{mS} \mathrm{cm}^{-1} \text { result- } \\
\text { ing from downward freezing of the } \\
\text { ground from the surface }\end{array}$ \\
\hline \multirow[t]{3}{*}{$2(16.0-9.95 \mathrm{~m})$} & 13.03 & 51200 & 700 & not calculable & $\begin{array}{l}\text { horizontally bedded grey-brown, } \\
\text { silty fine-grained sand }\end{array}$ \\
\hline & 11.15 & 54100 & 3400 & not calculable & \\
\hline & 10.53 & 50300 & 2100 & not calculable & \\
\hline $3(9.95-8.35 \mathrm{~m})$ & 8.83 & 53500 & 800 & not calculable & $\begin{array}{l}\text { inclined contact zone between the } \\
\text { ice wedge and encasing sediment, } \\
\text { grey-brown, silty fine-grained sand } \\
\text { ice wedge }\end{array}$ \\
\hline \multirow[t]{4}{*}{$5(3.4-0.35 \mathrm{~m})$} & 2.93 & 11400 & 50 & $13096-13304$ & grey-brown, silty, fine-grained sand \\
\hline & 2.5 & 11200 & 50 & $12996-13199$ & \\
\hline & 1.7 & 11100 & 50 & $12827-13090$ & \\
\hline & 0.7 & 10149 & 50 & $11603-12048$ & \\
\hline \multirow[t]{2}{*}{$6(0.35-0.0 \mathrm{~m})$} & 0.3 & 9700 & 50 & $11075-11238$ & $\begin{array}{l}\text { active layer, brown, silty fine- } \\
\text { grained sand, and modern top }\end{array}$ \\
\hline & 0.1 & modern & & & \\
\hline
\end{tabular}

solution (Th. Geyer, Germany), rinsed in purified water, followed by DNA-ExitusPlus treatment (VWR, Germany) and rinsing in purified water. Finally, the draw knife was soaked in $96 \%$ technical ethanol (Carl Roth GmbH \& Co. KG, Germany) and flamed. Then, about $1 \mathrm{~mm}$ of the newly exposed sediment was removed with a small clean knife (Th. Geyer, Germany). Each knife was used for one draw only. Before use, the small knife was cleaned with $5 \%$ Deconex-solution, rinsed in purified water, followed by DNA-Away ${ }^{\circledR}$ (Carl Roth $\mathrm{GmbH} \& \mathrm{ca}$. KG, Germany) treatment, and rinsed in purified water. Finally, each side of the knife was UV-irradiated at close distance for $10 \mathrm{~min}$ in a CL1000 ultraviolet crosslinker (UVP, USA), as recommended by Champlot et al. (2010).

The samples were drilled through the clean surface using a TCT hole saw with one tooth and an outer diameter of $25 \mathrm{~mm}$ (Esska.de $\mathrm{GmbH}$, Germany). Before use, they were cleaned in the same manner as the small knives. The ends of the retrieved cylindrical sediment pieces were cut using sterile disposable scalpel tips. After cutting the first end, the scalpel tip was cleaned using Deconex, rinsed with purified water and Ethanol, and finally flamed to prevent contamination from one end to the other. The DNA samples were stored at $-20^{\circ} \mathrm{C}$ and the pollen samples at $4{ }^{\circ} \mathrm{C}$. In total, 54 samples were drilled (approximately 3 to 4 samples per metre) for each kind of analysis. All 54 samples were analysed for sedaDNA while only 32 were processed for pollen analysis. The ice-wedge segment was not sampled for DNA analyses, because it was shattered into pieces, which were too small for an intact piece from the inside to be drilled out.

\subsection{Molecular genetic laboratory work}

DNA isolation and PCR setup was performed in the palaeogenetic laboratory of the Alfred-Wegener-Institute Helmholtz Centre for Polar and Marine Research in Potsdam, Germany. This lab is dedicated to ancient DNA isolation and PCR setup and is located in a building devoid of any molecular genetics lab work. The lab is cleaned frequently by the researchers and subjected to nightly UV-irradiation. All laboratory work was performed in a UVC/T-M-AR DNA/RNA cleaner-box (BIOSAN, Latvia). DNA isolations and PCR setups were performed on different days using dedicated sets of pipettes and equipment. Further precautions to reduce contamination included UV-irradiation of $10 \times$ buffer, BSA, $\mathrm{MgSO}_{4}$ and DEPC-treated water for $10 \mathrm{~min}$ in a UV crosslinker in thin-walled PCR reaction tubes approximately $1 \mathrm{~cm}$ below the UV light bulbs (similar to recommendations of Champlot et al., 2010).

Total DNA was isolated from approximately $5 \mathrm{~g}$ of frozen permafrost sediment using the PowerMax ${ }^{\circledR}$ Soil DNA Isolation Kit (Mo Bio Laboratories, Inc. USA). For the initial lysis and homogenization step, $0.8 \mathrm{mg}$ peqGOLD proteinase K (VWR, Germany), $0.5 \mathrm{~mL} 1 \mathrm{M}$ Dithiotreitol (VWR, Germany) and $1.2 \mathrm{~mL} \mathrm{C1}$ solution and samples were added to $15 \mathrm{~mL}$ PowerBead solution, vortexed for $10 \mathrm{~min}$ and incubated overnight at $56^{\circ} \mathrm{C}$ on a nutating mixer (VWR, Germany) under gentle agitation. All following steps were carried out according to the kit manufacturer's recommendations, using $1.6 \mathrm{~mL}$ elution buffer and extending the incuba- 
tion time to $10 \mathrm{~min}$ for the final elution. One extraction blank was included for each isolation batch of 11 samples and processed in the same way as the samples.

The PCR reactions were performed with the trnL $g$ and $\mathrm{h}$ primers (Taberlet et al., 2007). Both primers were modified on the $5^{\prime}$ end by unique $8 \mathrm{bp}$ tags which varied from each other in at least five base pairs to distinguish samples after sequencing (Binladen et al., 2007) and were additionally elongated by NNN tagging to improve cluster detection on the sequencing platform (De Barba et al., 2014). The PCR reactions contained 1.25 U Platinum ${ }^{\circledR}$ Taq High Fidelity DNA Polymerase (Invitrogen, USA), $1 \times$ $\mathrm{HiFi}$ buffer, $2 \mathrm{mM} \mathrm{MgSO}_{4}, 0.25 \mathrm{mM}$ mixed dNTPs, $0.8 \mathrm{mg}$ Bovine Serum Albumin (VWR, Germany), $0.2 \mathrm{mM}$ of each primer and $3 \mu \mathrm{L}$ DNA in a final volume of $25 \mu \mathrm{L}$. PCRs were carried out in a TProfessional Basic thermocycler (Biometra, Germany) with initial denaturation at $94^{\circ} \mathrm{C}$ for $5 \mathrm{~min}$, followed by 50 cycles of $94^{\circ} \mathrm{C}$ for $30 \mathrm{~s}, 50^{\circ} \mathrm{C}$ for $30 \mathrm{~s}, 68^{\circ} \mathrm{C}$ for $30 \mathrm{~s}$ and a final extension at $72^{\circ} \mathrm{C}$ for $10 \mathrm{~min}$. To trace possible contamination one no template control (NTC) was included in each PCR and treated identically to the samples and the extraction blanks. To check if the PCR was successful and whether the products matched the expected size, $2 \%$ agarose (Carl Roth $\mathrm{GmbH} \& \mathrm{Co}$. KG, Germany) gels were used .

For each sample, we pooled two positive amplifications for sequencing, under the condition that the associated NTCs and extraction blank were negative. The two pooled positive amplifications were purified using the MinElute PCR Purification Kit (Qiagen, Germany), following the manufacturer's recommendations. Elution was carried out twice with DEPC-treated ultra-purified water to a final volume of $40 \mu \mathrm{L}$. The DNA concentrations were estimated with the dsDNA BR Assay and the Qubit ${ }^{\circledR} 2.0$ fluorometer (Invitrogen, USA) using $1 \mu \mathrm{L}$ of the purified amplifications. To avoid bias based on differences in DNA concentration between samples, they were pooled in equimolar concentrations. All extraction blanks and NTCs were included in the sequencing run, using a standardized volume of $10 \mu \mathrm{L}$, even though they were negative in the PCRs. The sequencing results of extraction blanks and PCR controls are reported in the Supplement S4. Library preparation and sequencing on the Illumina HiSeq platform $(2 \times 125 \mathrm{bp})$ were performed by the Fasteris SA sequencing service (Switzerland).

\subsection{Analysis of sequence data and taxonomic assignments}

The sequence quality was checked using FastQC (Andrews, 2010) (Supplement S1, Fig. S3.1). Filtering, sorting and taxonomic assignments of the sequences were performed using OBITools (Boyer et al., 2016). Forward and reverse reads were aligned to produce single sequences using illuminapairedend. These sequences were assigned to their samples based on exact matches to their tag-combination using $n g s$ - filter, followed by obigrep to exclude sequences shorter than $10 \mathrm{bp}$ and obiuniq with which duplicated sequences were merged while keeping the information to which sample the sequences originally belonged. Rare sequences occurring with less than 10 read counts across the dataset were excluded as probable artefacts using obigrep. Sequence variants probably attributable to PCR or sequencing errors were excluded by obiclean (Boyer et al., 2016).

Two reference databases were used for taxonomic assignments as described in Epp et al. (2015): the first is based on the quality-checked and curated Arctic and Boreal vascular plant and bryophyte reference libraries (composed of 1664 vascular plant and 486 bryophyte species) published by Sønstebø et al. (2010), Willerslev et al. (2014) and Soininen et al. (2015); the second is based on the EMBL Nucleotide Database standard sequence release 117 (Kanz et al., 2005; http://www.ebi.acuk/embl/). The sequences were assigned to taxon names based on sequence similarity to each of the reference databases using ecotag. The nomenclature for the taxonomic assignment follows the NCBI taxonomy (Sayers et al., 2009). When the same taxonomic names were given more than once to different sequences we attached the affix MOTU (molecular operational taxonomic unit).

To further remove noise in the dataset, sequences occurring less than 10 times in a sample were excluded using R v. 3.0.3 (R Core Team, 2014). Only sequences that displayed a best identity value of 1.0 to an entry of a reference database were kept and assigned a taxonomic name (Supplement S5). Sequences which were assigned to cultivated plants or those highly unlikely to occur in the Arctic were excluded from our analyses as probable contamination (Supplement S6). These exotic DNA sequences were detected in almost all samples but contained mostly less than $1 \%$ of the total number of sequence counts with best identity of 1.0 (Supplement S6). The highest contribution of exotic DNA sequence counts within a sample was at $2.85 \mathrm{~m}$ depth from Musaceae. As a conservative measure we excluded sequences assigned to the PACMAD-clade (including Muhlenbergia richardsonis), since they are identical with Zea mays and authentic sequences cannot be distinguished from probable contamination. Nevertheless, the excluded sequences comprised only a small proportion $(3.3 \%)$ of all Poaceae sequences and an under-representation would thus have only a minor impact. Sequences appearing in the extraction blanks and NTCs comprised $3.4 \%$ of all sequence counts and were also excluded (Supplement S4). In most cases these sequences were only found in the extraction blanks $(55.6 \%)$ or NTCs $(33.3 \%)$ and not in the samples, while approximately $10 \%$ were probably derived from wrong sample assignment through tag-jumps.

\subsection{Pollen sample treatment and analysis}

For pollen analysis, 32 samples were selected . From each sample approximately $3 \mathrm{~g}$ (wet weight) were taken for sam- 
ple preparation. For fluid samples (unfrozen due to storage at $\left.4{ }^{\circ} \mathrm{C}\right) 1 \mathrm{~mL}$ of sediment was taken using a syringe. Standard preparation following Faegri and Iversen (1989) including $\mathrm{KOH}, \mathrm{HCl}$ and $\mathrm{HF}$ treatment was used to extract pollen, spores and algae from the sediment. For calculation of concentration of pollen a Lycopodium spore tablet (batch no. 1031; $n=20848 \pm 1460$ ) was added to each sample (Stockmarr, 1971). Pollen of terrestrial and aquatic plants as well as common spores and algae were analysed using a light microscope (Zeiss Axioskop 2) under 400-600 $\times$ magnification (Supplement S7). At least 300 pollen grains, spores and algae were identified in each sample following sample sizes in Andreev et al. (2011). Published pollen atlases (Beug, 2004; Kupriyanova and Alyoshina, 1972, 1978; Moore et al., 1991; Savelieva et al., 2013; Sokolovskaya, 1958) and a pollen reference collection at the Arctic and Antarctic Research Institute (Sankt-Petersburg) and the Alfred Wegener Institute were used for taxonomic identification of pollen and spores. Spores were determined according to van Geel (2001), van Geel et al. (1983), van Geel and Aptroot (2006). Freshwater algae were determined using Jankovská and Komárek (2000) and Komárek and Jankovská (2003).

\subsection{Statistical analyses and visualization}

Analyses for sedaDNA and pollen were carried out in the same manner. After first inspection of the data, we assigned Cyperaceae to the local component (Moore et al., 1991) of the swamp and aquatic taxa to get a better picture about changes in the terrestrial sedaDNA and pollen signals. We thus separated the data of both proxies into two datasets: (1) terrestrial and (2) swamp and aquatic. Recorded bryophytes for sedaDNA and spores were described, but since they were sparse, they could not be analysed statistically. Due to the higher taxonomic resolution of the sedaDNA, Kobresia (Cyperaceae) remained in the terrestrial sedaDNA set, while Poinae - either Arctophila fulva or Dupontia fisheri - were included in the swamp and aquatic set as both can occur within low-centred polygons (Aiken et al., 2007). Rarefaction curves were produced and rarefied taxon richness calculated using rarecurve and rarefy, to compare taxon richness at a particular number of sequences or pollen grains, determined by the lowest number of retrieved sequences or pollen grains among all samples (Heck et al., 1975; Hurlbert, 1971). This was performed for the terrestrial and swamp and aquatic datasets separately.

For statistical analyses, only taxa that were present in at least six samples in the terrestrial and in three samples in the taxonomically poorer swamp and aquatic datasets were included. Relative proportions of taxa within a sample were calculated on the basis of their sequence count or pollen sum in each dataset. A double square-root transformation was performed on the relative proportions of the sedaDNA dataset to mitigate the effect of over-represented and rare sequences, while square-root transformation was applied to the pollen dataset, since differences between counts were not as pronounced. A constrained hierarchical clustering approach (CONISS; Grimm, 1987) was performed with clusters constrained by depth using chclust. The relative proportions were thereafter transformed to Euclidean distances by vegdist. Zoning was guided by the broken-stick model (Bennett, 1996; MacArthur, 1957) using bstick, but with the condition that a minimum of five samples was necessary to assign a zone for the DNA datasets to avoid inflation of several very small zones. For pollen analysis a minimum of four samples was necessary to assign a zone, since fewer samples were taken compared to the DNA dataset. The stratigrams were plotted for each dataset separately with strat.plot.

Ratios of terrestrial to swamp and aquatic taxa and Poaceae to Cyperaceae were built (Mensing et al., 2008) to assess which contributed most to a sample, following Eqs. (1) and (2):

ratio $=\frac{\text { terrestrial }- \text { aquatic }}{\text { terrestrial }+ \text { aquatic }}$,
ratio $=\frac{\text { Poaceae }- \text { Cyperaceae }}{\text { Poaceae }+ \text { Cyperaceae }}$.

For this, the sums of sequence counts or pollen grains of (1) all terrestrial, (2) all swamp and aquatic taxa, (3) Poaceae and (4) Cyperaceae in a sample were built. The ratios range between -1.0 and 1.0 with negative values indicating dominance of swamp and aquatic or Cyperaceae sequences or pollen grains and positive values indicating dominance of terrestrial or Poaceae sequences or pollen grains, while a value of zero indicates an equal contribution of both.

A principal component analysis (PCA) was applied on the double square-root transformed relative proportions for sedaDNA and square-root transformed relative proportions for pollen using $r d a$ in order to portray the major structure in the multivariate dataset. Loadings for principle component 1 (PC1) and principal component 2 (PC2) axes were extracted and visualized in biplots. For better visibility, only terrestrial taxa that explained the most are plotted $(n=20$ for sedaDNA; $n=25$ for pollen).

The statistical analyses were performed in R v. 3.0.3 ( $\mathrm{R}$ Core Team, 2014) using the packages "vegan" (Oksanen et al., 2011), "rioja" (Juggins, 2012) and "analogue" (Simpson, 2007; Simpson and Oksanen, 2016). The age-depth model was built using the Bacon package (Blaauw and Christen, 2011) in R. The paleogenetic and palynological datasets are deposited at doi:10.1594/PANGAEA.870897. 


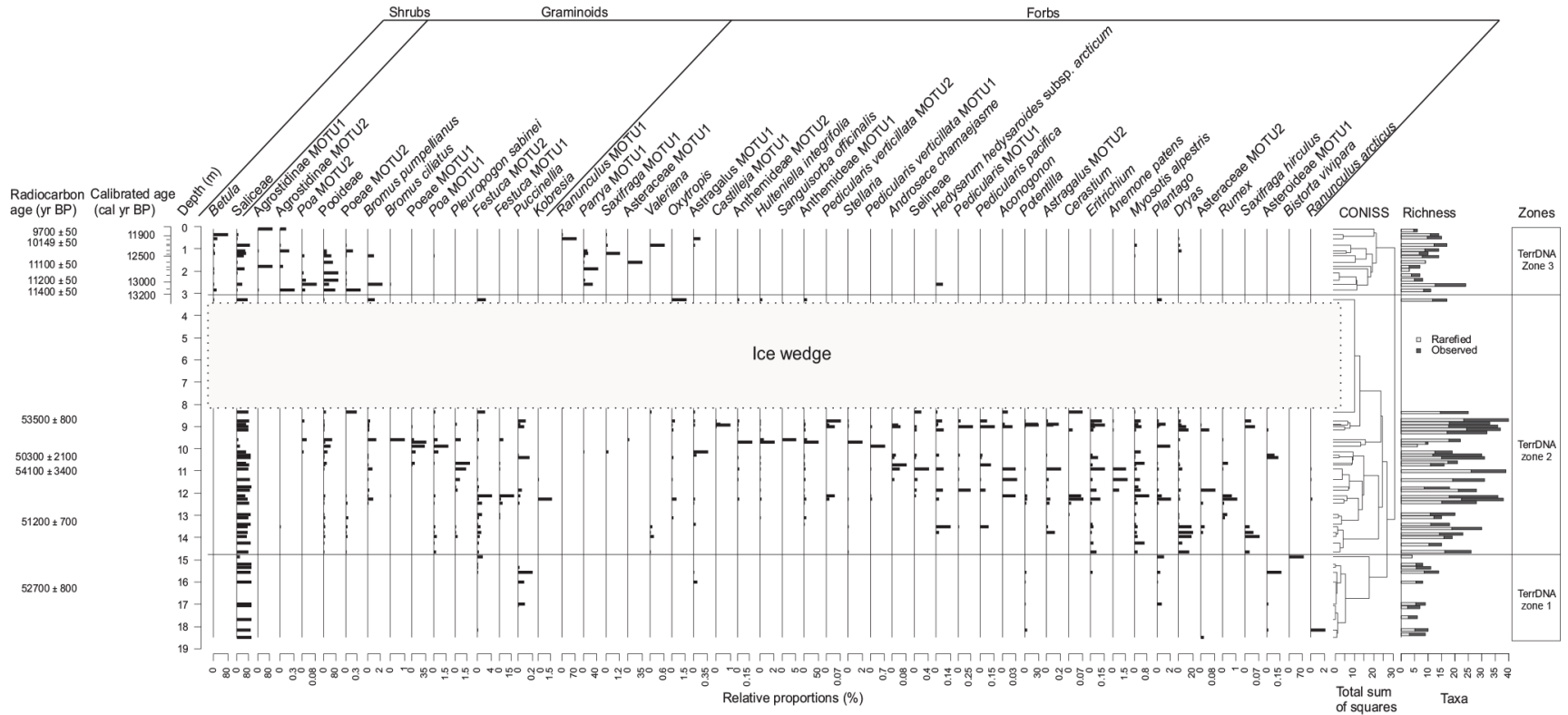

Figure 2. Stratigram of terrestrial sedaDNA (subset for statistical analyses) with relative proportions in percent of the taxa in each sample as horizontal bars, CONISS dendrogram, observed (dark grey) and rarefied (light grey) taxonomic richness. Uncalibrated radiocarbon ages are given with standard error in years before present ( $\mathrm{yr} \mathrm{BP}$ ) and calibrated ages from the age-depth model in calendar years before present (cal yr BP). The grey area indicates the ice wedge where no samples were taken. Horizontal lines indicate borders between zones. Scaling is taxon-specific for better visibility of low percentages.

\section{Results}

\subsection{SedaDNA}

\subsubsection{SedaDNA of terrestrial plants}

In total, 7238506 sequence counts were assigned to 113 terrestrial plant taxa, of which 40 were identified to species level, 49 to genus level, 22 to sub-tribe or family level, and 1 to order level.

Rarefaction analysis to compare richness on a similar level of sampling effort is based on the minimum number of observed sequence counts ( $n=1064,14.85 \mathrm{~m}$ depth). All curves of samples reach an asymptotic state, indicating a sufficient sampling effort in all samples (Fig. S3.2). The complete taxa list is available in Supplement S5.

No (authentic) tree taxa were detected, although Saliceae, Betula and Alnus occurred there as shrub form. $64.5 \%$ of all terrestrial sequence counts are from shrubs (Saliceae, Betula, Alnus), while $18.1 \%$ are from graminoids and $17.4 \%$ forbs. The dataset is particularly dominated by Saliceae sequences, which comprise $64 \%$ of all terrestrial sequence counts, followed by Pooideae (13\%), Agrostidinae MOTU1 (3\%), Ranunculus MOTU1 (3\%) and Betula (3\%).

According to the CONISS results, the terrestrial plant sedaDNA dataset can be divided into three zones (TerrDNA Zone) (Fig. 2). TerrDNA Zone 1 (18.48-14.85 m) displays low to high rarefied richness ranging from 2 to 26 taxa, with a median of 11 taxa. The lowest richness is found among the deepest samples from $14.85 \mathrm{~m}$ downwards. TerrDNA Zone 1 is dominated by Saliceae ranging from 22 to $99.8 \%$ (median $=91 \%$ ), accompanied by low proportions of Pooideae up to $24 \%($ median $=1 \%)$. The most frequent forb and graminoid taxa are Dryas (up to $20 \%$ ), Festuca MOTU1 (up to $19 \%$ ), Anthemideae MOTU1 (up to $7 \%$ ) and Potentilla (up to $6 \%$ ).

TerrDNA Zone $2(14.55-3.3 \mathrm{~m})$ frames the ice wedge $(8.35-3.4 \mathrm{~m})$ and exhibits the highest rarefied taxonomic richness, especially among graminoids, while forbs range from 6 to 24 taxa, median 17. Similar to TerrDNA Zone 1, Saliceae sequences dominate ranging from 0 to $83 \%$ (median $=60 \%$ ) while Anthemideae (up to $50 \%$ ), Pooideae (up to $56 \%$ ), Poeae MOTU1 (up to $36 \%$ ), Potentilla (up $31 \%$ ) and Dryas (up 13\%) have the highest proportions among graminoids and forbs. The sample at $3.3 \mathrm{~m}$ depth is the only sample of this zone above the ice wedge and shows an intermediate composition between TerrDNA Zone 2 and 3. It has lower richness in comparison to the samples below the ice wedge, but contains sequences of Anthemideae, Oxytropis, Festuca MOTU2 and Plantago, which are absent in TerrDNA Zone 3. However, it is the only sample of this zone to record Betula, although at a lower proportion than samples of TerrDNA Zone 3.

TerrDNA Zone 3 (2.85-0.1 m) displays a low to intermediate taxonomic richness ranging from 2 to 13 taxa (median $=8$ ). Several graminoid (e.g. Poeae MOTU1, Festuca, Pleuropogon sabinei) and forb taxa (e.g. Anthemideae, Po- 


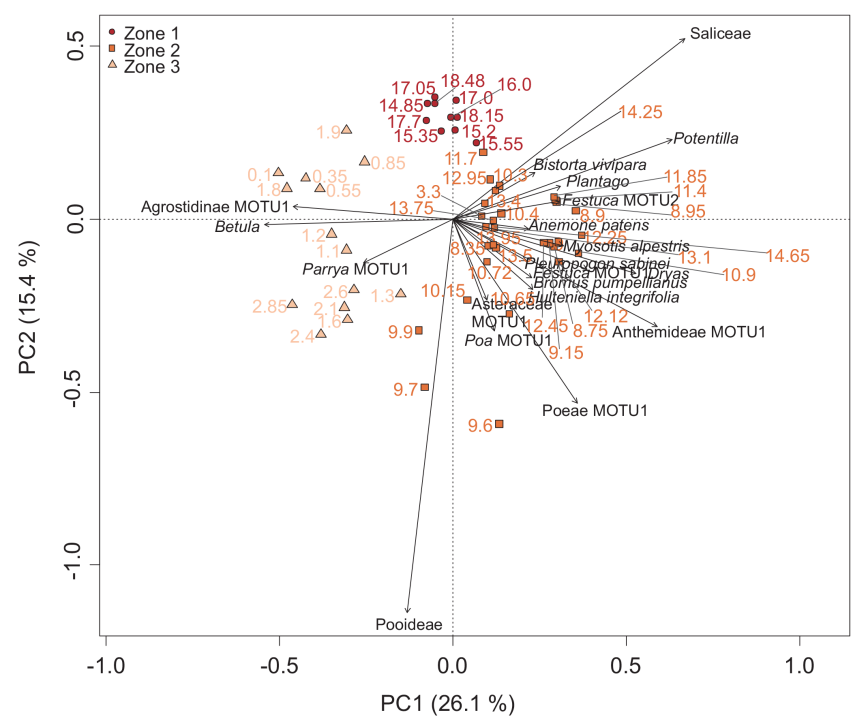

Figure 3. PCA biplot of terrestrial taxa from plant sedaDNA, showing a subset of 20 taxa which explained most of the variance in the dataset. Sample depths (m) are coloured according to their corresponding zone. Explained variances of the two principal components (PC) are shown in brackets.

tentilla, Hulteniella integrifolia) are not recorded. Characteristic is the presence of Betula sequences with proportions ranging from 0 to $63 \%$ (median $=2 \%$ ). Pooidae (up to $96 \%$, median $=16 \%$ ) and Saliceae (up to $86 \%$, median $=8 \%$ ) sequences dominate. Taxonomic composition is further characterized by Agrostidinae MOTU1 and 2 (up to $100 \%$ in the uppermost sample), Ranunculus MOTU1 (up to $74 \%$ ), Parrya (up to $44 \%$ ), Pyrola grandiflora (up to $26 \%$ ), Delphinium (up to $25 \%$ ), Ranunculaceae (up to $22 \%$ ) and Asteraceae (up to $20 \%$ ).

The PCA biplot of the first two axes (Fig. 3), jointly explaining $41.5 \%$ of the variance in the dataset, reveals the major structure of the terrestrial sedaDNA. Along PC1, Saliceae and Potentilla exhibit the highest loadings of 0.67 and 0.63, respectively, while Betula and Agrostidinae MOTU1 have the lowest negative loadings of -0.54 and -0.46 , respectively. Along PC2, Saliceae and Potentilla have the highest loadings of 0.52 and 0.23 , while Pooideae and Poeae MOTU1 show the lowest negative loadings of -1.14 and -0.53 , respectively. Samples of TerrDNA Zone 1 are placed mostly in the upper right quadrant and are partly intermixed with those of TerrDNA Zone 2, which are mostly placed in the lower right quadrant. TerrDNA Zone 3 samples are located in the upper and lower left quadrants and intermix only with the sample from $3.3 \mathrm{~m}$.

\subsubsection{SedaDNA of swamp and aquatic plants}

In total, 4591277 sequence counts were assigned to 21 swamp or aquatic taxa, of which 5 were assigned to species level, 15 to genus level and 1 to sub-tribe level. The most dominant sequences of the dataset are Carex aquatilis, comprising $66 \%$ of all sequence counts, followed by Eriophorum MOTU1 (11\%), Carex MOTU1 (8\%), Caltha palustris $(5 \%)$ and Poinae (Arctophila fulva or Dupontia fisheri) (4\%). Rarefaction is based on the minimum number of 20 sequence counts at $1.2 \mathrm{~m}$ depth. The rarefaction curves for all samples reach an asymptotic state, indicating sufficient sampling effort in all samples (Fig. S3.3).

The swamp and aquatic plant DNA dataset is divided into two zones (Fig. 4). AquaDNA Zone 1 (18.48-3.3 m) comprises all samples below the ice wedge plus a single sample above the ice wedge at $3.3 \mathrm{~m}$. The rarefied taxonomic richness of this zone ranges between 0 and 5 with a median of 1 . In the deepest part of this zone (14.85-18.48 m) 3 out of 10 samples exhibit aquatic sequences from a single taxon with small numbers of sequence counts (up to 85). AquaDNA Zone 1 is dominated by Caltha palustris up to $97 \%$, Carex MOTU1 up to $100 \%$ and Carex aquatilis up to $100 \%$. Hydrophytes such as Stuckenia and Hippuris are characteristically present with proportions up to 63 and $4 \%$, respectively.

AquaDNA Zone $2(2.85-0.1 \mathrm{~m})$ comprises all samples above the ice wedge, except for the sample at $3.3 \mathrm{~m}$ depth. This zone exhibits a lower rarefied taxonomic richness than AquaDNA Zone 1 (Fig. 4). Samples between 2.4 and $1.2 \mathrm{~m}$ display high proportions of Equisetum up to $100 \%$ (median $=54 \%$ ) followed by Eriophorum MOTU1 up to $99 \%$ $($ median $=12 \%)$. Near surface parts at $1.1-0.1 \mathrm{~m}$ depth are dominated by Poinae up to $50 \%$, Carex MOTU1 up to $45 \%$ and Tephroseris up to $17 \%$. Hydrophytes are not present whereas Caltha palustris is present at $0.55 \mathrm{~m}$ with a proportion of less than $1 \%$. Sedges are only represented by Carex aquatilis and Carex MOTU1.

The PCA biplot of the first two axes (Fig. 5), jointly explain $48.79 \%$ of the variance in the dataset. Along PC1 Caltha palustris and Carex aquatilis demonstrate the highest loadings of 0.86 and 0.85 , respectively, while Equisetum exhibits the only negative loading of -1.11 . Along PC2 Poinae and Caltha palustris exhibit the highest loadings of 0.91 and 0.62, respectively, while Carex MOTU1 and Carex aquatilis have the lowest negative loadings of -0.79 and -0.46 , respectively. AquaDNA Zone 1 samples are located mostly in the right quadrants and partly intermix with those of AquaDNA Zone 2, which are mostly located in the left quadrants.

\subsubsection{SedaDNA of bryophytes and algae}

In total, 8482 sequence reads were assigned to 19 bryophyte taxa and 1 alga (Table 2), which constitutes $0.07 \%$ of all sequences. Seven taxa were assigned to species level, including the freshwater alga Cosmarium botrytis (John et al., 2002), four to genus level, five to family level and four to order level. The observed number of taxa varies between one and 


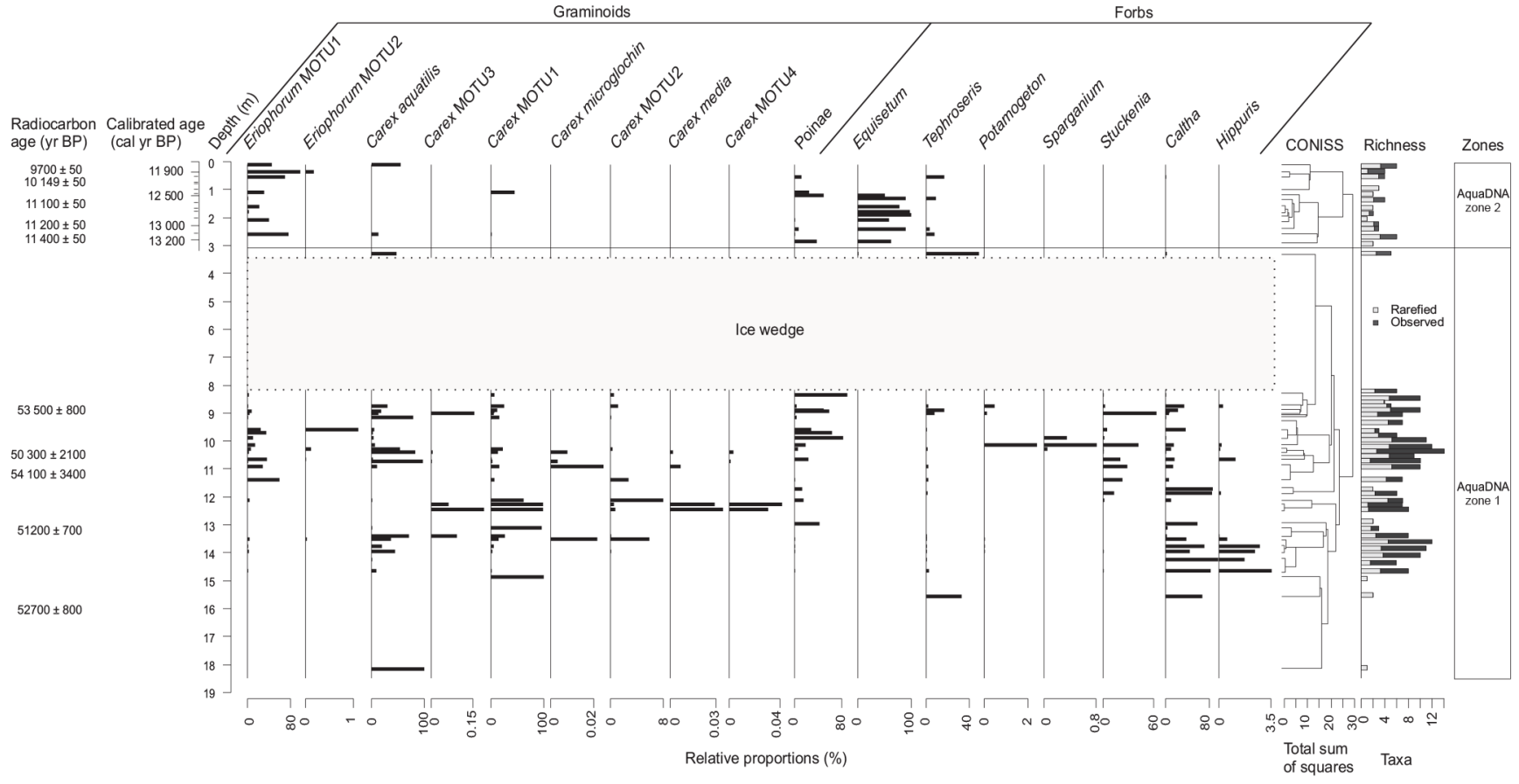

Figure 4. Stratigram of swamp and aquatic sedaDNA (subset for statistical analyses) with relative proportions in percent of the taxa in each sample as horizontal bars, CONISS dendrogram, observed (dark grey) and rarefied (light grey) taxonomic richness. Uncalibrated radiocarbon ages are given with standard error in years before present (yr BP) and calibrated ages from the age-depth model in calendar years before present (cal yr BP). The grey area indicates the ice wedge where no samples were taken. The horizontal line indicates the border between the zones. Scaling is taxon-specific for better visibility of low percentages.

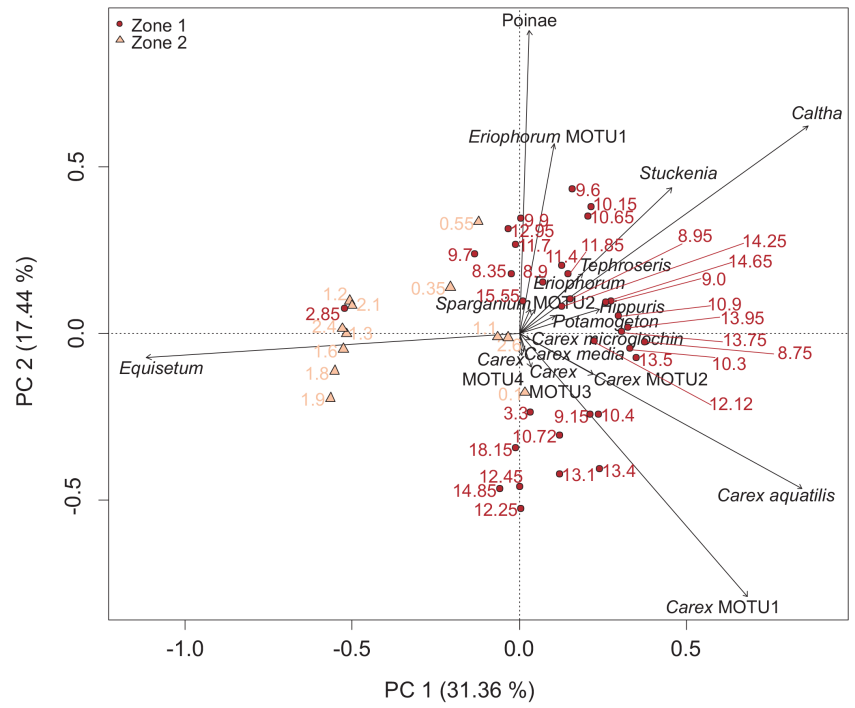

Figure 5. PCA biplot of swamp and aquatic taxa from plant sedaDNA. Sample depths $(\mathrm{m})$ are coloured according to their corresponding zone. Explained variances of the two principal components (PC) are shown in brackets. six. $82.31 \%$ of all cryptogam sequence reads are assigned to Sphagnum (37.39\%) and Sphagnum russowii $(44.92 \%)$ at $3.3 \mathrm{~m}$ : the depth at which the highest number of bryophyte taxa is recorded.

\subsection{Pollen}

\subsubsection{Pollen of terrestrial plants}

A total of 8580 terrestrial pollen grains were counted and ascribed to 53 taxa, while 248 were indeterminable and 53 assigned as pre-Quaternary pollen. From this, 7 taxa were assigned to species type or section level, 24 taxa to genus level, 21 to family level, and 1 to order level. Rarefaction is based on the minimum number of 137 pollen counts at $11.7 \mathrm{~m}$ depth. The rarefaction curves did not reach saturation, implying that the sampling effort was insufficient to display the sample diversities (Figs. S3.4, S3.5).

The core is divided into three terrestrial palynological zones (Fig. 6). TerrPZ 1 (18.48-17.2 m) displays the highest rarefied richness, ranging from 18 to 21 taxa $($ median $=20)$. This zone is distinguished by the presence of pollen from shrubs, especially Betula sect. Nanae with proportions up to $15 \%$, Alnus fruticosa-type up to $8 \%$ and Salix up to $11 \%$. Poaceae with proportions up to $50 \%$, Brassicaceae up to $10 \%$ and Artemisia up to $7 \%$ dominate among the graminoid 


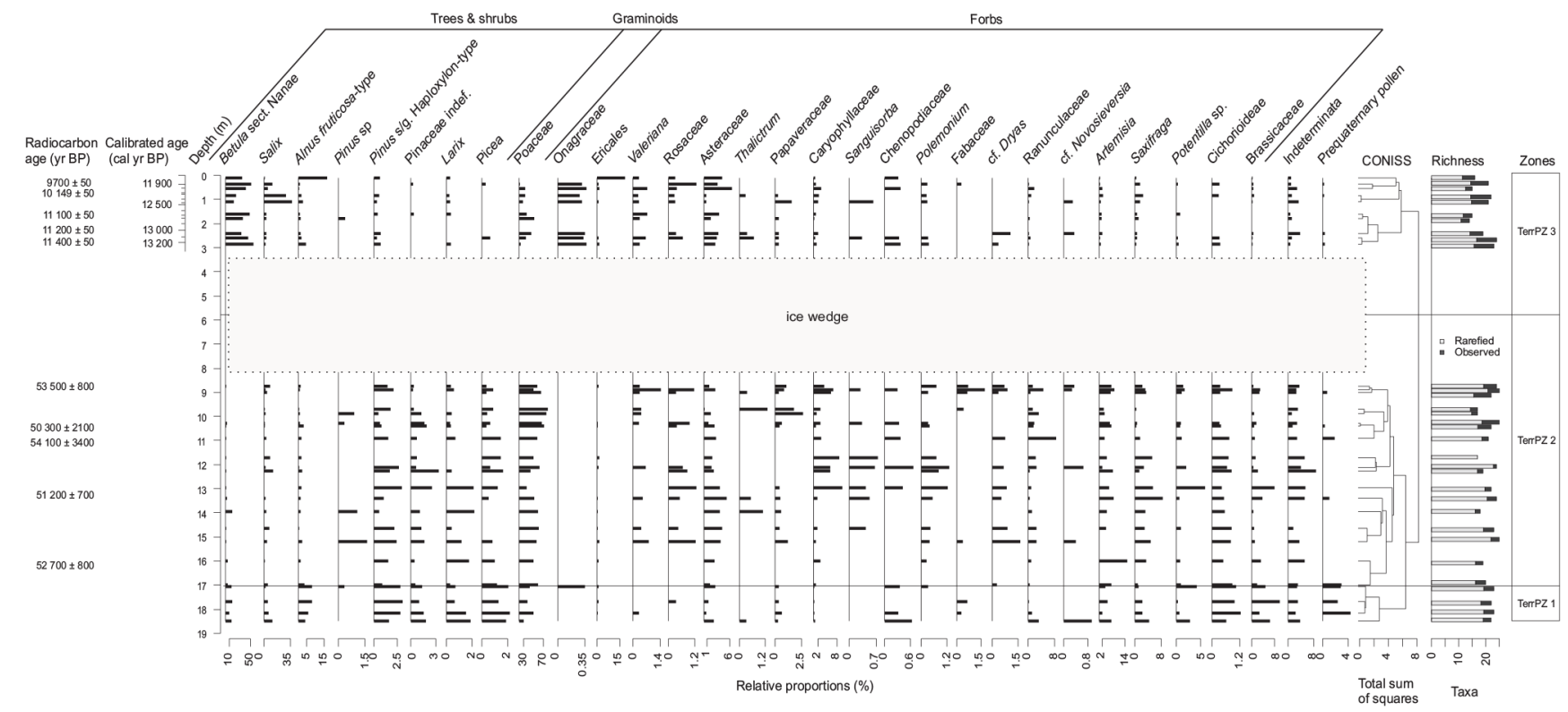

Figure 6. Stratigram of terrestrial pollen (subset for statistical analyses) with relative proportions in percentage of the taxa in each sample as horizontal bars, CONISS dendrogram, observed (dark grey) and rarefied (light grey) taxonomic richness. Uncalibrated radiocarbon ages are given with standard error in years before present ( $\mathrm{yr} \mathrm{BP}$ ) and calibrated ages from the age-depth model in calendar years before present (cal yr BP). The grey area indicates the ice wedge where no samples were taken. Horizontal lines indicate borders between palynological zones. Scaling is taxon-specific for better visibility of low percentages.

and forb taxa. Pollen from trees comprise, among others, $P i$ nus Haploxylon-type up to $3 \%$ and Larix up to $2 \%$. Furthermore, the major proportion of redeposited, pre-Quaternary pollen can be found in this zone, while total pollen concentration is the lowest (Table 3).

For TerrPZ $2(17.05-8.75 \mathrm{~m})$ relatively high taxonomic richness is registered ranging from 15 to 26 taxa, median 19 taxa. This zone is characterized by a decrease in pollen from trees and shrubs with decreasing depth and a dominance of forb and graminoid taxa, especially Poaceae with proportions up to $79 \%$. Artemisia, Asteraceae, Caryophyllaceae, Brassicaceae, Ranunculaceae and Saxifragaceae dominate among other forbs. Furthermore, a remarkable proportion of cf. Dryas of up to $2 \%$ is seen in this zone.

TerrPZ $3(2.85-0.1 \mathrm{~m})$ displays a lower rarefied richness of 11-19 taxa (median =14). This zone is dominated by Betula sect. Nanae (up to $54 \%$ ), Salix (up to $38 \%$ ) and Poaceae (up to $51 \%$ ). In the samples of 0.85 and $1.3 \mathrm{~m}$, large proportions of Salix are present at $30 \%$ and $38 \%$, respectively. The proportion of Artemisia decreases and ranges between 1 and $2 \%$. The uppermost sample is characterized by large increases of Alnus fruticosa-type (up to $17 \%$ ) and Ericales (up to $18 \%$ ), reflecting the recent pollen spectrum.

The first two axes in the biplot (Fig. 7) jointly explain $55 \%$ of the variance in the dataset. Along PC1 Poaceae and Artemisia exhibit the highest loadings of 0.44 and 0.23 , respectively, while Betula sect. Nanae and Salix have negative loadings of -0.94 and -0.17 , respectively. Along PC 2 the highest positive loadings belong to Poaceae and Salix with 0.31 and 0.28 , respectively, while Brassicaceae and Alnus fruticosa-type exhibit the lowest negative loadings of -0.37 and -0.31 , respectively. The upper right quadrant includes mostly shrub taxa, the upper left quadrant mostly coniferous trees and the lower quadrants mostly open-land taxa. Samples of TerrPZ 1 plot mostly in the lower left and right quadrants, samples of TerrPZ 2 plot in the upper and lower left quadrants and samples of TerrPZ3 plot in the upper and lower left quadrants, without intermixing.

\subsubsection{Pollen and spores of swamp and aquatic plants}

A total of 2816 aquatic pollen grains and spores were counted and ascribed to 8 taxa, of which 6 were assigned to genus level and 2 to family level. The numbers of aquatic pollen grains are low and vary between 15 and 220 per sample. Rarefaction curves, based on the minimum number of pollen grains ( $n=15 ; 16 \mathrm{~m}$ depth), do not reach saturation, implying insufficient sampling effort and an underestimate of the sample's diversity (Fig. S3.6). The broken-stick model recommends three zones, but under the condition that each zone must consist of at least four samples, two aquatic palynological zones are assigned (Fig. 8).

AquaPZ $1(18.48-16.0 \mathrm{~m})$ consists of the deepest part of the core. Rarefied richness ranges from one to two with a median of two. Cyperaceae dominate with proportions of 73$96 \%($ median $=92 \%)$. The sum of proportions from other taxa accounts for less than $10 \%$, except for the sample at 
Table 2. Number of sequence counts for bryophyte taxa detected by sedaDNA in the corresponding sample depths.

\begin{tabular}{|c|c|c|c|c|c|c|c|c|c|c|c|c|c|c|c|c|c|c|c|c|}
\hline 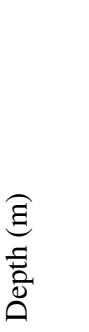 & 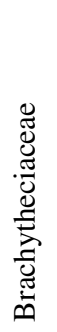 & 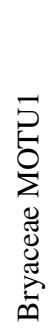 & 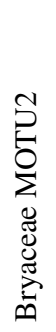 & 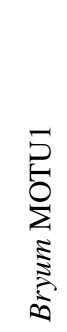 & 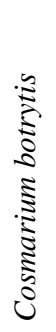 & $\begin{array}{l}\frac{\tilde{u}}{\tilde{J}} \\
\stackrel{\tilde{J}}{\tilde{U}} \\
\stackrel{0}{0}\end{array}$ & 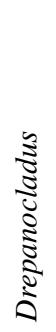 & 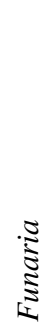 & 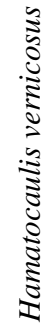 & 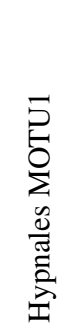 & 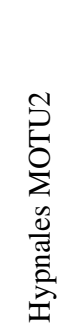 & 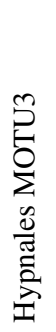 & 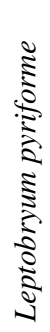 & 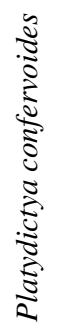 & 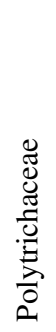 & 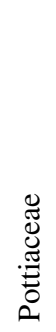 & 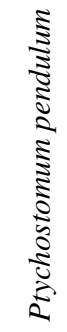 & 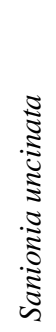 & $\underset{\frac{5}{5}}{\frac{5}{5}}$ & 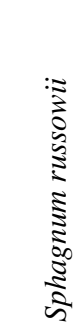 \\
\hline 0.35 & 0 & 0 & 0 & 14 & 0 & 30 & 0 & 0 & 0 & 0 & 0 & 0 & 0 & 0 & 0 & 0 & 0 & 0 & 0 & 0 \\
\hline 2.60 & 0 & 0 & 0 & 27 & 60 & 0 & 0 & 0 & 0 & 0 & 0 & 12 & 42 & 0 & 0 & 0 & 0 & 0 & 0 & 0 \\
\hline 2.85 & 0 & 0 & 0 & 0 & 0 & 0 & 0 & 0 & 82 & 0 & 0 & 0 & 0 & 0 & 0 & 0 & 0 & 0 & 0 & 0 \\
\hline 3.30 & 0 & 0 & 0 & 0 & 0 & 0 & 0 & 0 & 0 & 0 & 148 & 0 & 0 & 0 & 39 & 0 & 157 & 89 & 3171 & 3810 \\
\hline 8.35 & 0 & 12 & 0 & 41 & 0 & 0 & 0 & 0 & 0 & 0 & 0 & 0 & 0 & 0 & 0 & 13 & 0 & 0 & 0 & 0 \\
\hline 8.75 & 0 & 14 & 19 & 203 & 0 & 0 & 0 & 0 & 0 & 0 & 0 & 0 & 0 & 0 & 0 & 0 & 0 & 0 & 0 & 0 \\
\hline 8.90 & 10 & 0 & 0 & 27 & 0 & 0 & 0 & 0 & 0 & 0 & 0 & 0 & 0 & 0 & 0 & 0 & 0 & 10 & 0 & 0 \\
\hline 8.95 & 0 & 0 & 0 & 23 & 0 & 0 & 0 & 0 & 0 & 0 & 0 & 0 & 0 & 0 & 0 & 0 & 0 & 0 & 0 & 0 \\
\hline 9.00 & 0 & 0 & 0 & 17 & 0 & 0 & 15 & 0 & 0 & 236 & 0 & 0 & 0 & 56 & 0 & 0 & 0 & 0 & 0 & 0 \\
\hline 9.60 & 0 & 0 & 0 & 0 & 0 & 0 & 0 & 0 & 0 & 75 & 0 & 0 & 0 & 0 & 0 & 0 & 0 & 0 & 0 & 0 \\
\hline 10.40 & 0 & 0 & 0 & 0 & 0 & 0 & 0 & 30 & 0 & 0 & 0 & 0 & 0 & 0 & 0 & 0 & 0 & 0 & 0 & 0 \\
\hline
\end{tabular}

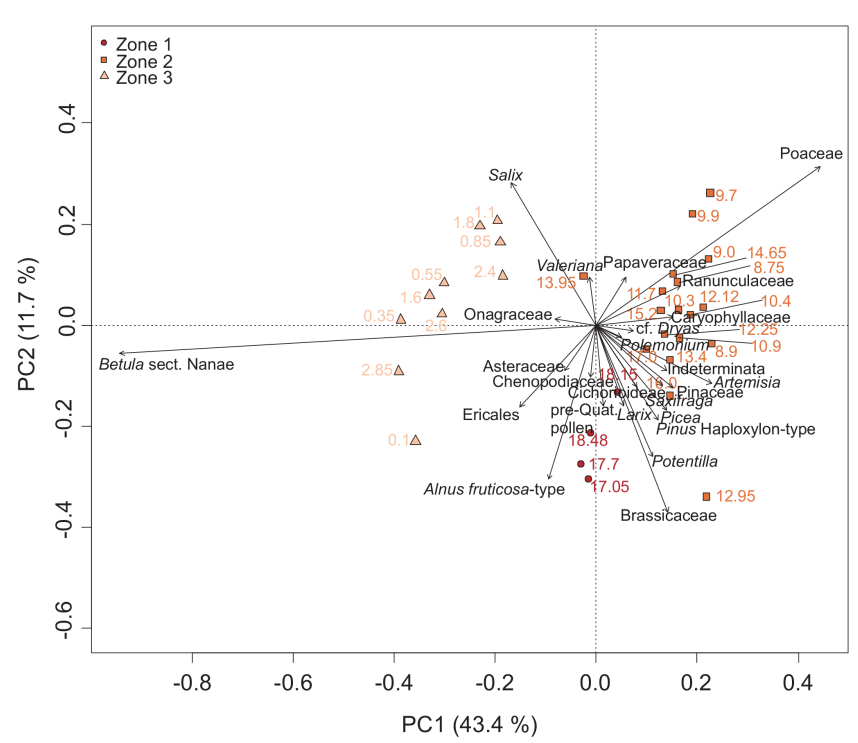

Figure 7. PCA biplot of terrestrial taxa from pollen analysis, showing a subset of 23 taxa, indeterminate and pre-Quaternary pollen, which explained most of the variance in the dataset. Sample depths (m) are coloured according to their corresponding zone. Explained variances of the two principal components (PC) are shown in brackets.

$16.0 \mathrm{~m}$, which was co-dominant with Equisetum at $27 \%$, while the sample at $17.0 \mathrm{~m}$ is co-dominant with cf. Potamogeton at $13 \%$.

AquaPZ 2 (15.2-0.1 m) comprises nearly the whole core. Rarefied richness ranges from 1 to 2 with a median of 1 . The proportions of Cyperaceae range from 92 up to $100 \%$ (me- dian $=98 \%$ ). The sum of all further taxa account for less than $10 \%$ in each sample.

The first two axes in the biplot (Fig. 9) jointly explain $75 \%$ of the variance in the aquatic pollen dataset. Equisetum displays the only positive loading along PC1 of 0.67 , while cf. Potamogeton has the lowest negative loading of -0.42 . Along PC2, cf. Potamogeton has the highest positive loading of 0.58 and Cyperaceae has the lowest negative loading of 0.17. Samples from AquaPZ 1 are located in the upper quadrants of the biplot while most of the samples from AquaPZ 2 are located in the lower quadrants.

\subsubsection{Spores and algae}

A total of 1092 spores and algae were counted and assigned to 25 taxa, comprising 4 mosses, 2 spikemosses, 6 clubmosses, 3 ferns, 6 fungi and 4 green algae (Table 3). In samples below the ice wedge, the most abundant algae and plant spores belong to green algae, especially Pediastrum, Botryococcus, Zygnema-type, and Bryales. The most abundant fungal spores are Sporormiella and Glomus, with Glomus only being recorded in the deepest parts of the core from $14.65 \mathrm{~m}$ downwards, as well as in the sample at $8.9 \mathrm{~m}$. Similar to the redeposited pollen, the major proportion of preQuaternary spores can be found between 17.05 and $18.15 \mathrm{~m}$. Above the ice wedge, Gelasinospora, Zygnema-type, Botryococcus, Bryales and Sphagnum are relatively abundant.

\subsection{Ratios of terrestrial to swamp and aquatic taxa and Poaceae to Cyperaceae}

Ratios were built for the sedaDNA and pollen datasets to assess whether terrestrial or swamp and aquatic taxa con- 
Table 3. Number of spores, algae, pre-Quaternary spores and total pollen concentration for each sample.

\begin{tabular}{|c|c|c|c|c|c|c|c|c|c|c|c|c|c|c|c|c|c|c|c|c|c|c|c|c|c|c|c|}
\hline 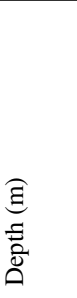 & 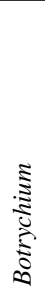 & 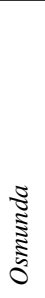 & 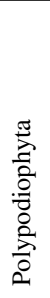 & $\underset{\tilde{D}}{\stackrel{\tilde{w}}{\pi}}$ & 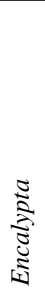 & 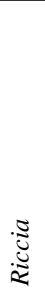 & 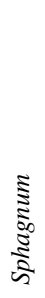 & 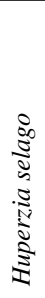 & 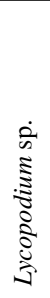 & 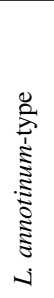 & 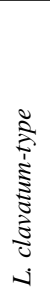 & 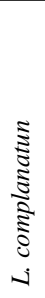 & 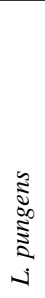 & 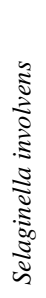 & 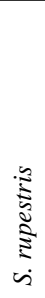 & $\frac{\sqrt{0}}{\frac{0}{0}}$ & 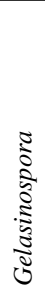 & 离 & 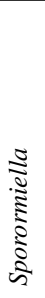 & $\frac{\sqrt[3]{5}}{\sqrt[3]{5}}$ & $\frac{\mathfrak{\Xi}}{\mathbb{\Xi}}$ & 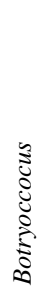 & $\begin{array}{l}\mathbf{\Xi} \\
\mathbf{5} \\
\vdots \\
\vdots \\
0 \\
0 \\
2\end{array}$ & 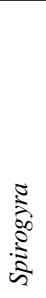 & 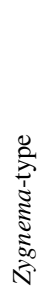 & 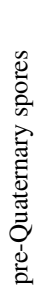 & 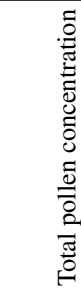 \\
\hline 0.10 & 0 & 0 & 0 & 0 & 0 & 0 & 6 & 0 & 0 & 0 & 0 & 1 & 1 & 0 & 0 & 0 & 0 & 0 & 0 & 0 & 0 & 2 & 1 & 0 & 1 & 0 & 13899 \\
\hline 0.35 & 0 & 0 & 1 & 1 & 1 & 0 & 0 & 0 & 0 & 0 & 0 & 0 & 0 & 0 & 0 & 0 & 13 & 0 & 0 & 0 & 0 & 0 & 1 & 0 & 4 & 2 & 28585 \\
\hline 0.55 & 0 & 0 & 0 & 4 & 0 & 0 & 0 & 0 & 0 & 0 & 0 & 0 & 0 & 0 & 1 & 0 & 38 & 0 & 0 & 0 & 1 & 0 & 0 & 0 & 4 & 0 & 11992 \\
\hline 0.85 & 0 & 2 & 2 & 0 & 2 & 1 & 0 & 0 & 0 & 0 & 0 & 0 & 0 & 0 & 1 & 0 & 37 & 0 & 0 & 0 & 0 & 1 & 0 & 0 & 1 & 0 & 19649 \\
\hline 1.10 & 0 & 0 & 0 & 0 & 0 & 0 & 1 & 1 & 0 & 0 & 0 & 0 & 0 & 0 & 0 & 0 & 9 & 0 & 0 & 0 & 0 & 1 & 0 & 0 & 13 & 0 & 20472 \\
\hline 1.60 & 0 & 0 & 0 & 0 & 0 & 0 & 2 & 0 & 0 & 0 & 0 & 0 & 0 & 0 & 1 & 0 & 0 & 0 & 0 & 0 & 0 & 3 & 0 & 0 & 0 & 0 & 38090 \\
\hline 1.80 & 0 & 0 & 1 & 0 & 0 & 0 & 0 & 0 & 0 & 0 & 0 & 0 & 0 & 0 & 0 & 0 & 0 & 0 & 0 & 0 & 0 & 1 & 0 & 1 & 1 & 0 & 48965 \\
\hline 2.40 & 0 & 0 & 0 & 8 & 0 & 1 & 2 & 1 & 0 & 0 & 0 & 0 & 0 & 0 & 0 & 1 & 5 & 0 & 0 & 0 & 0 & 2 & 0 & 0 & 2 & 0 & 24976 \\
\hline 2.60 & 0 & 0 & 0 & 0 & 1 & 1 & 1 & 1 & 0 & 0 & 0 & 0 & 0 & 0 & 1 & 0 & 3 & 0 & 0 & 0 & 0 & 0 & 1 & 0 & 1 & 0 & 28102 \\
\hline 2.85 & 0 & 0 & 0 & 1 & 1 & 1 & 1 & 1 & 0 & 0 & 0 & 0 & 0 & 0 & 1 & 1 & 10 & 0 & 0 & 0 & 0 & 1 & 1 & 0 & 0 & 0 & 23954 \\
\hline 8.75 & 0 & 0 & 2 & 1 & 0 & 1 & 1 & 0 & 0 & 0 & 0 & 0 & 0 & 0 & 1 & 0 & 0 & 0 & 0 & 0 & 0 & 7 & 3 & 0 & 1 & 0 & 8166 \\
\hline 8.90 & 1 & 0 & 0 & 2 & 1 & 0 & 3 & 0 & 0 & 1 & 0 & 0 & 0 & 0 & 5 & 1 & 0 & 0 & 1 & 0 & 5 & 7 & 5 & 0 & 1 & 1 & 11294 \\
\hline 9.00 & 0 & 0 & 0 & 1 & 0 & 0 & 0 & 1 & 0 & 1 & 0 & 0 & 0 & 0 & 2 & 0 & 0 & 0 & 0 & 0 & 0 & 3 & 2 & 0 & 6 & 0 & 38324 \\
\hline 9.70 & 0 & 0 & 0 & 8 & 0 & 1 & 0 & 0 & 0 & 0 & 0 & 0 & 0 & 0 & 0 & 0 & 0 & 0 & 0 & 0 & 0 & 5 & 2 & 0 & 3 & 0 & 20328 \\
\hline 9.90 & 0 & 0 & 0 & 25 & 1 & 0 & 0 & 0 & 0 & 0 & 1 & 0 & 0 & 0 & 0 & 0 & 0 & 0 & 0 & 0 & 0 & 1 & 0 & 0 & 6 & 0 & 22580 \\
\hline 10.30 & 1 & 0 & 1 & 0 & 1 & 0 & 2 & 0 & 0 & 0 & 0 & 0 & 0 & 0 & 1 & 0 & 0 & 0 & 0 & 0 & 0 & 6 & 5 & 0 & 4 & 0 & 27350 \\
\hline 10.40 & 0 & 0 & 1 & 4 & 1 & 0 & 1 & 0 & 0 & 0 & 0 & 1 & 1 & 0 & 1 & 0 & 0 & 0 & 0 & 0 & 0 & 6 & 5 & 0 & 3 & 0 & 14078 \\
\hline 10.90 & 0 & 0 & 3 & 0 & 1 & 1 & 2 & 1 & 0 & 0 & 0 & 0 & 0 & 0 & 1 & 0 & 0 & 0 & 0 & 0 & 0 & 9 & 8 & 0 & 2 & 0 & 9203 \\
\hline 11.70 & 0 & 0 & 0 & 4 & 1 & 0 & 1 & 0 & 0 & 0 & 0 & 0 & 0 & 0 & 1 & 0 & 0 & 0 & 0 & 0 & 0 & 0 & 2 & 0 & 8 & 0 & 13912 \\
\hline 12.12 & 0 & 0 & 1 & 3 & 1 & 1 & 1 & 1 & 0 & 0 & 0 & 0 & 0 & 0 & 2 & 0 & 0 & 0 & 1 & 0 & 0 & 2 & 12 & 0 & 2 & 1 & 29315 \\
\hline 12.25 & 0 & 0 & 2 & 7 & 1 & 0 & 0 & 0 & 1 & 0 & 0 & 0 & 0 & 0 & 4 & 0 & 0 & 0 & 0 & 0 & 0 & 6 & 5 & 0 & 4 & 0 & 11327 \\
\hline 12.95 & 0 & 1 & 2 & 16 & 0 & 2 & 1 & 0 & 0 & 0 & 0 & 0 & 0 & 0 & 1 & 0 & 0 & 0 & 27 & 0 & 0 & 3 & 49 & 0 & 3 & 0 & 10792 \\
\hline 13.40 & 0 & 0 & 1 & 10 & 1 & 1 & 3 & 1 & 1 & 0 & 0 & 0 & 1 & 0 & 1 & 0 & 0 & 0 & 2 & 0 & 0 & 5 & 4 & 0 & 4 & 1 & 11221 \\
\hline 13.95 & 0 & 0 & 1 & 1 & 0 & 0 & 0 & 0 & 0 & 0 & 0 & 1 & 0 & 0 & 1 & 0 & 0 & 0 & 0 & 0 & 0 & 6 & 0 & 0 & 2 & 0 & 4170 \\
\hline 14.65 & 1 & 0 & 4 & 0 & 2 & 1 & 2 & 0 & 0 & 0 & 0 & 0 & 1 & 0 & 1 & 0 & 0 & 0 & 0 & 0 & 3 & 8 & 0 & 0 & 2 & 0 & 8575 \\
\hline 15.20 & 0 & 0 & 1 & 10 & 4 & 1 & 2 & 0 & 0 & 0 & 0 & 0 & 1 & 0 & 1 & 0 & 0 & 4 & 0 & 0 & 2 & 4 & 3 & 0 & 7 & 0 & 10691 \\
\hline 16.00 & 0 & 1 & 2 & 4 & 1 & 0 & 7 & 0 & 0 & 0 & 0 & 0 & 1 & 3 & 0 & 0 & 0 & 0 & 0 & 0 & 3 & 4 & 1 & 0 & 1 & 0 & 12148 \\
\hline 17.00 & 0 & 0 & 2 & 9 & 0 & 0 & 6 & 0 & 0 & 0 & 2 & 0 & 1 & 0 & 2 & 0 & 0 & 0 & 9 & 1 & 1 & 7 & 10 & 0 & 0 & 0 & 6710 \\
\hline 17.05 & 0 & 0 & 5 & 1 & 4 & 0 & 7 & 0 & 0 & 0 & 0 & 0 & 0 & 0 & 1 & 0 & 0 & 0 & 2 & 0 & 7 & 9 & 12 & 0 & 2 & 1 & 4974 \\
\hline 17.70 & 0 & 0 & 2 & 2 & 2 & 0 & 7 & 0 & 0 & 0 & 0 & 1 & 0 & 0 & 1 & 0 & 0 & 0 & 2 & 0 & 1 & 13 & 16 & 0 & 1 & 3 & 13223 \\
\hline 18.15 & 1 & 1 & 4 & 0 & 1 & 1 & 6 & 0 & 1 & 0 & 2 & 0 & 1 & 0 & 3 & 0 & 0 & 0 & 7 & 0 & 1 & 17 & 63 & 0 & 3 & 1 & 9691 \\
\hline 18.48 & 1 & 1 & 4 & 20 & 3 & 0 & 8 & 0 & 1 & 0 & 1 & 0 & 0 & 0 & 1 & 0 & 0 & 0 & 7 & 0 & 12 & 14 & 21 & 0 & 3 & 0 & 3778 \\
\hline
\end{tabular}

tributed more sequences or pollen grains to a sample and were compared to the corresponding Poaceae-Cyperaceae ratios. This allowed us to trace local hydrological changes and to identify drier (positive values) and wetter phases (negative values) (Fig. 10). Generally, sedaDNA and pollen show similar trends for both ratios, with an exception between 11.7 and $12.12 \mathrm{~m}$ depth. The Poaceae-Cyperaceae ratio of the sedaDNA exhibits highly fluctuating ratios across the core and mostly follows the pattern of the terrestrial-aquatic ratio. A total of 18 sedaDNA samples are dominated by swamp and aquatic taxa: 4 above the ice wedge and 14 below. The pollen ratios show more moderate fluctuations and only two samples are dominated by swamp and aquatic taxa at 11.7 and $12.12 \mathrm{~m}$ depth. However, in six samples Cyperaceae dominate over Poaceae, one at $2.85 \mathrm{~m}$ and five between $11.7 \mathrm{~m}$ and $14.65 \mathrm{~m}$, whilst samples between 13.0 and $14.0 \mathrm{~m}$ have equal contributions of Poaceae and Cyperaceae pollen.

\section{Discussion}

\subsection{Quality and proxy value of sedaDNA and pollen data}

All samples from the BK-8 sediment core contained plantderived DNA and pollen. The two proxies are known to complement each other (e.g. Jørgensen et al., 2012), and differences in the obtained data result mostly from the spatial scale at which sedaDNA and pollen originate (local vs. regional signal) and technical biases, which lead to variations in the taxonomic richness, the level of taxonomic resolution and the strength of taphonomic processes in both proxies.

The different spatial scales of sedaDNA (local) and pollen (local to extra-regional) records are an important aspect of the differences identified in the taxon spectra and thus indicate complementarity rather than direct comparability of the proxies. In most of the samples we did not detect conifer- 


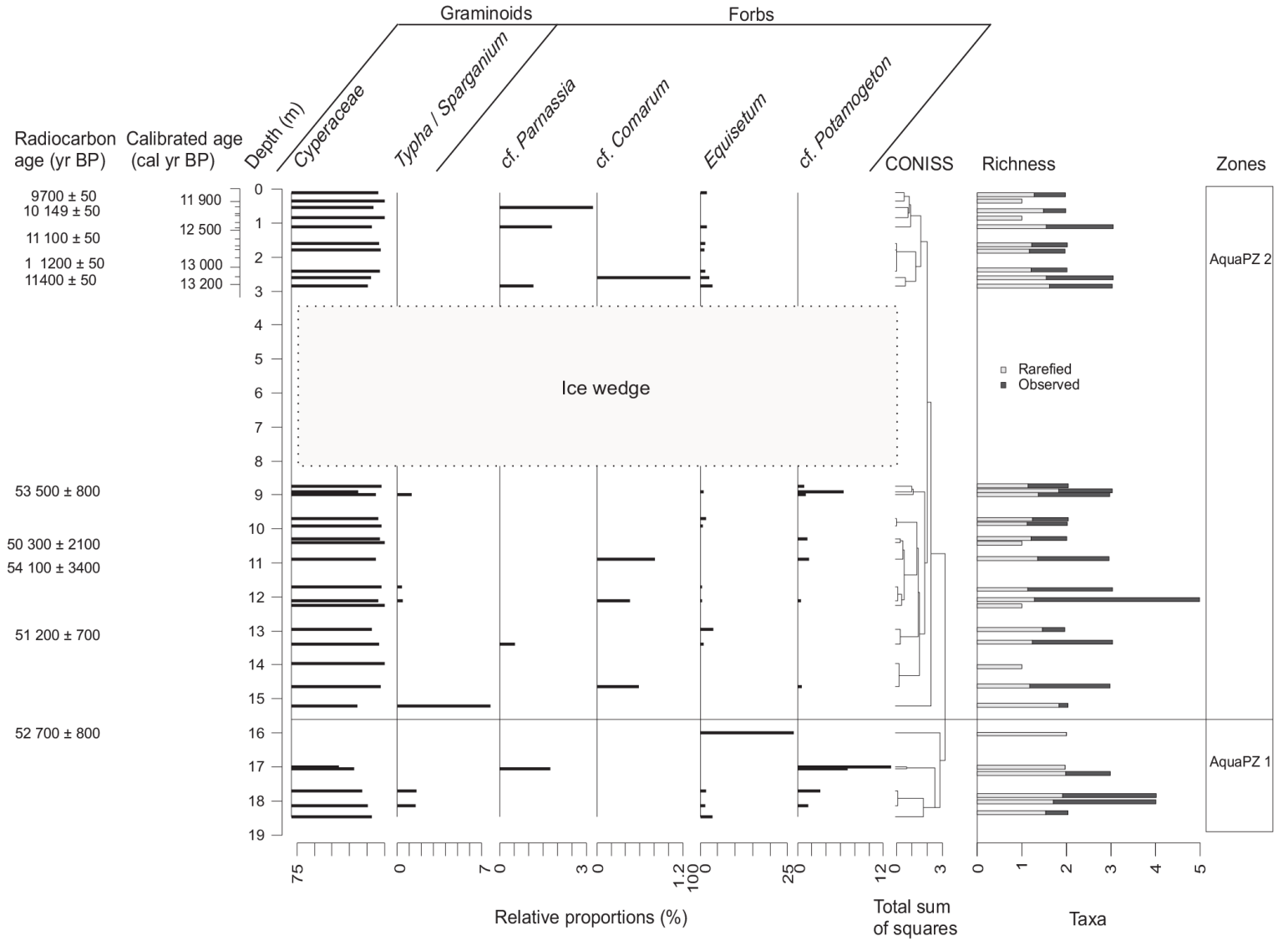

Figure 8. Stratigram of swamp and aquatic pollen and/or spores with relative proportions of the taxa in each sample as horizontal bars and CONISS dendrogram. The grey area indicates the ice wedge where no samples were taken. Uncalibrated radiocarbon ages are given with standard error in years before present (yr BP) and calibrated ages from the age-depth model in calendar years before present (cal yr BP). The horizontal line indicates the border between the palynological zones. Scaling is taxon-specific for better visibility of low percentages.

derived sedaDNA, although they are present in the pollen record. Hence, the Pinaceae pollen presumably originated from extra-regional stands (Birks, 2001; van der Knaap, 1987). Furthermore, the applied sedaDNA marker is located on the chloroplast genome, which is transmitted through pollen in Pinaceae (reviewed in Mogensen, 1996). If pollen contributed significantly to the sedaDNA record, we would expect to find it at least in samples with high Pinaceae proportions, which we did not. This supports two assumptions about sedaDNA: first, that sedaDNA originates mainly locally (Haile et al., 2007, 2009; Jørgensen et al., 2012; Parducci et al., 2013; Pedersen et al., 2016; Sjögren et al., 2016; Yoccoz et al., 2012) and, second, that it is predominantly derived from roots and other plant parts rather than from pollen (Jørgensen et al., 2012; Levy-Booth et al., 2007; Parducci et al., 2013; Pedersen et al., 2016; Sjögren et al., 2016; Willerslev et al., 2003). Overall, we find a steady dominance of Saliceae (which we interpret as Salix), Poaceae and Cyperaceae sequences across all samples of the core. This is likely caused by the huge below-ground biomass of these taxa in tundra environments, which can far exceed the above-ground biomass.
According to Iversen et al. (2015), the ratio of below- to above-ground biomass in tundra is highest for sedges and grasses, followed by shrubs, and is lowest for forbs. Since Salix is also found throughout the pollen record, we assume that it was locally present throughout the investigated time frame. This further supports the general view that sedaDNA mainly presents a local signal.

Technical and taphonomic biases of pollen data are well known. For example, standard pollen sample preparation, as applied in this study, may (partly) destroy Luzula and Larix pollen grains (Moore et al., 1991). Hydrophytes are largely under-represented in the pollen dataset when compared to the sedaDNA results, which may be caused by low pollen production or insufficient sedimentation, as pollen from, e.g., Potamogeton tends to float on the water surface for pollination (Cox, 1988; Preston and Croft, 1997). While taphonomic biases in sedaDNA are still not well understood and part of ongoing research, especially for lake sediments (Alsos et al., 2015), the technical biases of sedaDNA are known and have been reviewed in Hansen et al. (2006), Schnell et al. (2015) and Thomsen and Willerslev (2015). We found an inflation of 


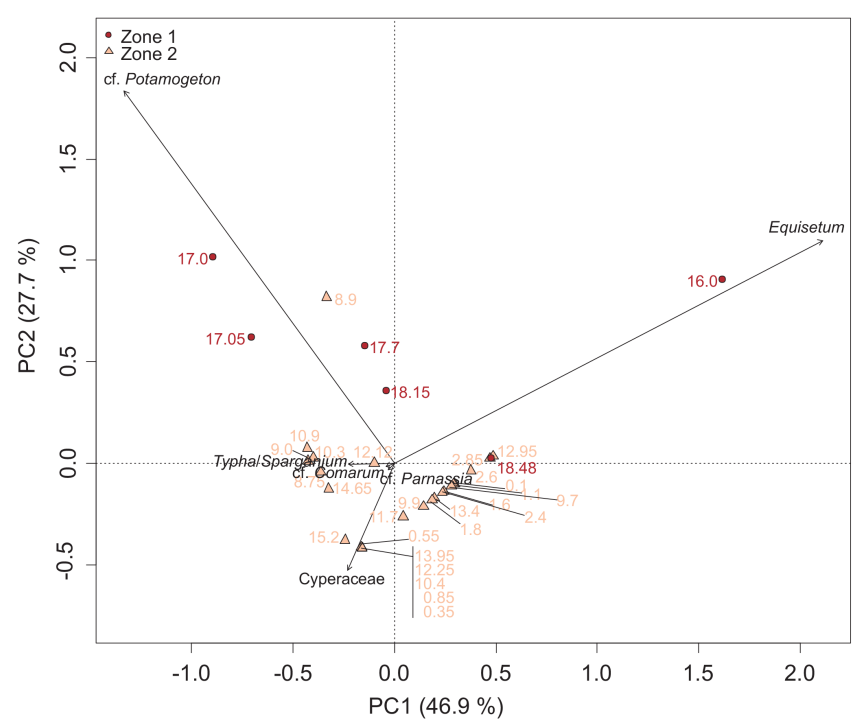

Figure 9. PCA biplot of swamp and aquatic taxa from pollen analysis. Sample depths (m) are coloured according to their corresponding zone. Explained variances of the two principal components (PC) are shown in brackets.

unique sequence types, attributable to PCR errors, across the whole dataset, except for those which we deemed as possible contamination. Otherwise, our dataset shows low probabilities for erroneous base calls indicated by high sequencing qualities. We therefore assume that the taxa included in the analyses are authentic. A more detailed technical evaluation can be found in Supplement S2.

Compared to the number of vascular plant taxa (58) and bryophytes (4) recorded by pollen analysis, the sedaDNA approach recorded a higher number of both vascular plants (134) and bryophytes (20). Next to technical biases and taphonomy, the lower number of taxa recorded by pollen can be explained by the sampling effect and the taxonomic resolution. The counts of sequences and pollen grains differed by several orders of magnitude, which is reflected in rarefaction curves of sedaDNA reaching saturation while those of pollen do not. This indicates that our sequencing depth was adequate for sedaDNA. The number of pollen counts was guided by pollen records for the Laptev region, usually ranging between 100 and 600 counts (Andreev et al., 2011). However, for future studies a higher sampling effort should be considered. The recorded richness also depends on the taxonomic resolution, which depends on the marker employed for sedaDNA. The resolution of the trnL P6 loop marker (Taberlet et al., 2007) allowed assignment of $78 \%$ of the retrieved sequences to species or genus level, while $71 \%$ of pollen, spores and algae were identified to a similar taxonomic level. This is in the range of other sedaDNA studies focusing on Arctic vegetation from permafrost sediments (Taberlet et al., 2007: $90 \%$ up to genus level, Sønstebø et al., 2010: $83 \%$ for the oldest and $68 \%$ for the youngest sample, Jørgensen et al.,

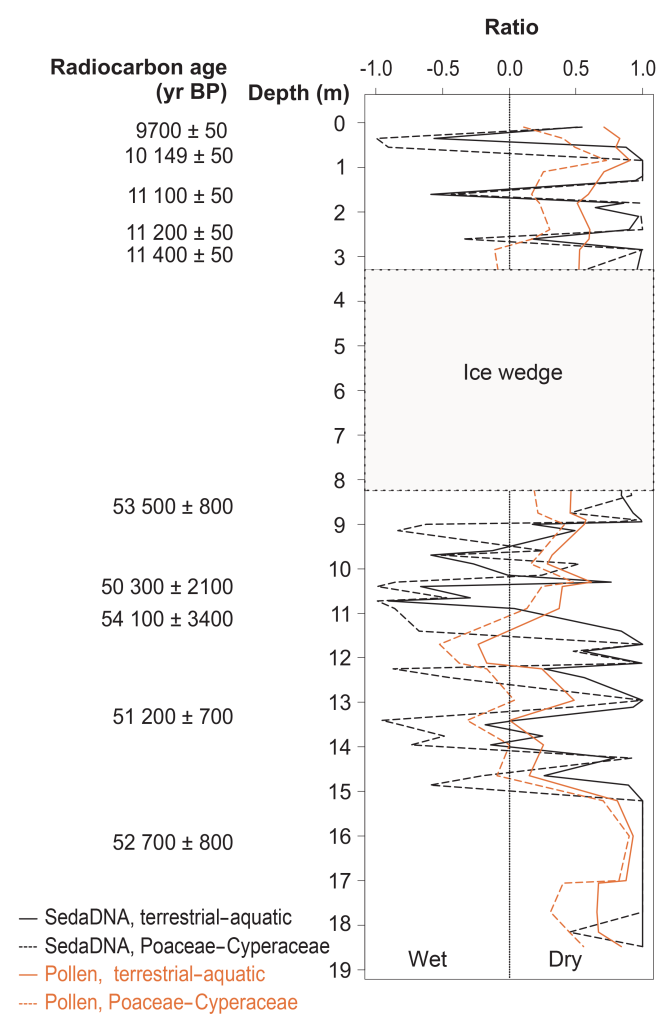

Figure 10. Terrestrial-aquatic (Eq. 1) (line) and PoaceaeCyperaceae ratios (Eq. 2) (dashed line) of plant sedaDNA (black) and pollen (red). Positive ratios indicate a higher contribution of terrestrial or Poaceae sequence counts or pollen grains and hence drier conditions. Negative ratios indicate a higher contribution of swamp and aquatic or Cyperaceae sequence counts or pollen grains and hence wetter conditions. Uncalibrated radiocarbon ages are given in years before present (yr BP).

2012: $81 \%$, Willerslev et al., 2014: $80 \%$ ). SedaDNA analysis was able to resolve 21 sequence types from Poaceae and Cyperaceae on the species or genus level. Although some of the sequence types within these families cannot be resolved due to insufficient variation in the marker region, they cannot be distinguished by pollen analysis either (Birks, 2001). A higher resolution would provide a better estimate of the taxonomic richness and thus greater insight into local environmental conditions. Additionally, we found that bryophytes are highly under-represented in our datasets, despite being reported to be highly abundant, diverse and functionally very important members of modern polygonal landscapes (Zibulski et al., 2013, 2016). Epp et al. (2012) developed a marker for bryophyte metabarcoding with an approximately $10 \%$ higher resolution than the trnL P6 loop. Their marker, however, had a low amplification success rate in late Pleistocene samples. They highlighted two probable causes, which might hold true for the trnL P6 marker. First, the main bryophyte biomass is typically found above-ground, whereas roots are suspected to contribute the majority of vascular plant DNA in 
soil (Levy-Booth et al., 2007; Willerslev et al., 2003; Yoccoz et al., 2012), and second, the presence of secondary metabolites may increase DNA degradation rates after cell lysis (e.g. Xie and Lou, 2009).

Lastly, sedaDNA richness depends on the completeness of the reference database (Jørgensen et al., 2012; Parducci et al., 2013; Pedersen et al., 2013). By using the Arctic-Boreal reference database (Soininen et al., 2015; Sønstebø et al., 2010; Willerslev et al., 2014), we were able to increase the resolution for many taxa, plus the EMBL database allowed us to examine our sequences for possible contamination by food or cultivated plants.

\subsection{Environmental conditions during the pre-LGM (54-51 kyr BP, 18.9-8.35 m) and composition of deposited organic matter}

The major part of the core below the ice wedge encompasses sediments deposited before the Last Glacial Maximum (LGM). According to sedaDNA and pollen this part can be divided into two zones; however the boundary between these zones differs slightly between the terrestrial and swamp and aquatic datasets and lies between 15 and $17 \mathrm{~m}$. The zonation matches the major structure presented in the PCA biplots of sedaDNA and pollen. The pollen record from the whole core portrays an open landscape at the regional scale. Below the ice wedge the core shows fluctuating ages associated with high standard deviations, which can be explained either by the radiocarbon dating method being at its limit or by reworking of the sediments.

The deepest part of the core from 18.9 to $\sim 16$ m sedaDNA reflects a local terrestrial flora with low taxonomic richness, comprising taxa such as Plantago, Puccinellia and Potentilla, with Carex aquatilis as the only wetland plant retrieved at $18.15 \mathrm{~m}$ depth. The pollen record of this zone is characterized by high proportions of shrub, Poaceae and tree pollen, but with low proportions of Larix. As Larix pollen has a very limited dispersal capacity owing to its size, weight and low quantity (Niemeyer et al., 2015; Sjögren et al., 2008), Larix stands are inferred to have been in the regional vicinity of the coring site, possibly even closer than they are today. In contrast to sedaDNA, high proportions of Pediastrum, Botryococcus and Zygnema-type algae and highest proportions of Potamogeton pollen overall imply the presence of a shallow pond (Andreev et al., 2002; Kienast et al., 2005). Only in this zone do the sedaDNA and pollen records show such distinct differences. In the deepest $2.5 \mathrm{~m}$ the amount of redeposited pre-Quaternary pollen and spores is highest (up to $\sim 5 \%$ ) among all samples. According to the sedimentary and hydrogeochemical results presented in Schirrmeister et al. (2016), this part of the core implies an ancient active layer. An active layer is prone to disturbances such as erosion, cryoturbation (through seasonal thawing and refreezing) and potentially also grazing, all of which allow for redeposition of older material.
At depths from approximately $16 \mathrm{~m}$ until the ice wedge at $8.35 \mathrm{~m}$, sedaDNA and pollen reveal high taxonomic richness. SedaDNA portrays high diversity among grasses and forbs including swamp and aquatic taxa and high proportions of Salix. In several samples the sedaDNA record is dominated by Cyperaceae and other swamp and aquatic taxa, with mostly negative values on the ratio plot, especially for the sedaDNA dataset. This indicates wet conditions on a local scale and probably enhanced organic matter accumulation, as cold and anoxic conditions reduce decomposition rates (Davidson et al., 2000). These findings are supported by the sedimentary, hydrogeochemical (Schirrmeister et al., 2016) and biomarker analyses (Stapel et al., 2016) performed on the same core. Schirrmeister et al. (2016) and Stapel et al. (2016) identified less decomposed organic matter at depths of $10 \mathrm{~m}$ and between 11.2 and $15 \mathrm{~m}$ from higher total organic carbon (TOC) content, higher hydrogen index, lower $\delta^{13} \mathrm{C}$ values and high concentrations of branched Glycerol dialkyl glycerol tetraether (br-GDGTs, microbial membrane compounds). The taxonomic composition of sedaDNA comprised typical taxa of low-centred polygonal depressions such as Stuckenia, Hippuris and Caltha palustris, indicating the presence of a shallow pond (Kienast et al., 2008). Intermittently, the absence of hydrophytes and increasing proportions of Poinae (Arctophila fulva/Dupontia fisheri) and Cyperaceae indicate times without a pond and hence point towards temporal fluctuations in the hydrology of the depression. The temporal scale on which these fluctuations occurred, however, cannot be assessed due to cryoturbation in the sediments and the large uncertainties of the dating results.

As shown by recent studies of low-centred polygons, microtopographical differences resulting from the moisture gradient between the dry uplifted ridge and the wet depression shape the local plant community (de Klerk et al., 2009, 2011; Zibulski et al., 2016). According to the sedaDNA results, Carex probably occupied the major part of the polygon, whereas the ridge was likely covered by Salix along with Poaceae and forbs (de Klerk et al., 2009, 2011, 2014; Minke et al., 2007, 2009; Teltewskoi et al., 2016). The transitional zone from the ridge to the depression is characterized by an increase in moisture and was probably occupied by taxa such as Carex, Eriophorum, Comarum and Pedicularis (de Klerk et al., 2009, 2014; Savelieva et al., 2013; Zibulski et al., 2016). However, vegetation surveys along transects through modern low-centred polygons and temporal reconstructions from short cores (de Klerk et al., 2009, 2011, 2014; Minke et al., 2007, 2009; Teltewskoi et al., 2016; Zibulski et al., 2016) show high proportions of Vaccinium, Ledum palustre, Empetrum nigrum and Betula nana ssp. exilis and therefore display a different composition of Holocene polygons in comparison to our findings. This indicates that Holocene polygon mires might differ from those of the pre-LGM.

The palynological record in this zone $(16-8.35 \mathrm{~m})$ comprises Potamogeton pollen, Pediastrum, Botryococcus and Zygnema-type algae, which supports the presence of a shal- 
low pond (Andreev et al., 2002; Kienast et al., 2005). Artemisia, Dryas and Papaveraceae indicate overall dry environmental conditions with probably more severe winters than today, while Potamogeton indicates warmer summers (Kienast et al., 2001, 2005). Annual precipitation of less than $250 \mathrm{~mm}$ and rapidly falling temperatures in winter must have occurred to allow thermal cracking of the soil to keep the active layer sufficiently shallow for the formation of ice wedges and ridges that enclose low-centred polygons (Minke et al., 2007). Low relative pollen proportions of trees from extraregional stands and shrubs with high proportions of grasses, sedges and forbs are consistent with other published pollen and macrofossil analyses in this time interval and region (Andreev et al., 2011; Kienast et al., 2001; Sher et al., 2005). The recorded pollen spectra from our core furthermore tally with studies from the central Laptev region, in which pollen records are dominated by Cyperaceae and Poaceae with a constant presence of Salix and high abundances of Artemisia and Caryophyllaceae for 55 to $40 \mathrm{kyr} \mathrm{BP}$ (Andreev et al., 2011, and references therein). The decreasing proportions of Larix pollen with decreasing depth presented here may point towards a retreat of Larix stands or a reduction in pollen productivity through unfavourable environmental conditions.

\subsection{Environmental conditions during the post-LGM (11.4-9.7 kyr BP (13.4-11.1 cal kyr BP)) and composition of deposited organic matter}

The permafrost core was drilled at the top of a Yedoma hill (Schirrmeister et al., 2016). Wind and rain probably eroded most of the Holocene deposits, resulting in a hiatus between the sample of the modern core top and the second sample at $0.25 \mathrm{~m}$ depth $(11.1 \mathrm{cal} \mathrm{kyr} \mathrm{BP})$. The upper part of the core consists of sediments dated to the transition from the late glacial to the early Holocene (13.4-11.1 cal kyr BP). As emphasized in Andreev et al. (2011), records of the late glacial transition are rare because of active thermoerosion. Hence, our results provide valuable information about the vegetation history in this region and organic matter composition. The sedaDNA results imply profound changes after the LGM, which is displayed in the major structure of the terrestrial PCA biplot. First, the local taxonomic richness decreased strongly. Second, the taxonomic composition of the local flora changed towards shrub tundra and was mainly characterized by high proportions of Betula, Salix and Equisetum with a low diversity among Poaceae and forbs with only a subset of the formerly present Cyperaceae. Highly fluctuating proportions, especially between Poaceae and Cyperaceae, indicate fluctuating moisture conditions but not the presence of a pond. In relatively drier periods, indicated by positive values in the ratio plot, the organic matter comprises mostly Poaceae, which were represented by a different composition in comparison to the pre-LGM, with Agrostidinae and Poa MOTU2. During moister periods, indicated by negative values in the ratio plot, increased proportions of wetland plants such as Eriophorum, Equisetum and Ranunculus were recorded. The high proportions of Equisetum in this time interval are supported by our spore record as well as in the palaeogenetic study of Willerslev et al. (2014) and the palynological review of Andreev et al. (2011).

The pollen analysis shows that the same dominant taxa detected by sedaDNA characterize the area on a regional scale and implies shrub tundra with Salix, Betula and Alnus (Andreev et al., 2011). The equal relative proportions between pollen from trees and shrubs and pollen from forbs, grasses and sedges indicate climate amelioration during the early Holocene (Andreev et al., 2011) with increased humidity after the marine transgression (Kienast et al., 2001). Shrub pollen increased in the Laptev Sea region approximately at 9 kyr BP (Andreev et al., 2011), while in the Khorogor Valley near Tiksi an increase, especially of Betula pollen, of up to $60 \%$ was already recorded at $11.54 \pm 0.06 \mathrm{kyr} \mathrm{BP}$ (Grosse et al., 2007; Khg-11). In this study the increase is recorded at $11.4 \pm 0.05 \mathrm{kyr} \mathrm{BP}$ and therefore matches well with the pollen data of the Khorogor Valley. The uppermost samples are dominated by Poaceae followed by Cyperaceae pollen and show high proportions of Alnus, Betula and Salix along with Ericales and Ranunculaceae but low proportions of Artemisia, reflecting the modern pollen spectrum (Andreev et al., 2011; CAVM Team, 2003). In contrast, the sedaDNA surface sample is characterized by Agrostidinae, Eriophorum MOTU1 and Carex aquatilis. This most likely reflects their root biomass in this sample. Taken together, both proxies reflect the tussock-sedge, dwarf-shrub tundra according to the division of the Circumpolar Arctic Vegetation Map (CAVM Team, 2003).

\section{Conclusions}

We demonstrate that combining sedaDNA with palynological analyses for palaeobotanical reconstructions offers valuable insights into the taxonomic composition of plant organic matter and its accumulation conditions. The proxies complement each other and differences between the records result mainly from differences in the spatial resolution, the taxonomic resolution capacities and the sampling effort.

The sedaDNA record presents a high number of taxa at a high resolution throughout the core, allowing a detailed characterization of plant community changes in the deposited sediments. Furthermore, the high taxonomic resolution allowed for inferences of hydrological changes at the coring site. Our findings support the general view that sedaDNA represents the local flora and predominantly local belowground biomass.

Pollen, spores and algae prove to be important for a more complete representation of the taxonomic composition on a local to regional scale and to assess the environmental conditions. They are suitable in tracing hydrological changes at the coring site, even though the signal can be buffered by the 
regional and extra-regional pollen input and hence is not as pronounced as with sedaDNA.

For sediments deposited from 54 to $51 \mathrm{kyr} \mathrm{BP}$, the pollen record suggests an open landscape shaped by relatively dry environmental conditions. Plant organic matter composition, derived from sedaDNA, reveals high taxonomic richness among grasses, sedges and forbs, including hydropyhtes with a constant presence of Salix. The fluctuating dominance of swamp and aquatic taxa in both proxies suggests the presence of a low-centred polygon, which frequently carried a pond in the depression, implying that severe winters prevailed, which allowed for frost cracking and polygon development. Comparisons with studies of Holocene polygons indicate that preLGM plant communities of low-centred polygons differed from Holocene ones.

During the post-LGM (11.4-9.7 kyr BP (13.411.1 cal kyr BP)), sedaDNA shows an almost complete taxonomic turnover to shrub tundra with less taxonomic richness in comparison to the pre-LGM deposits. Similar to the sedaDNA record, pollen also implies shrub tundra during the post-LGM, but in contrast to sedaDNA, the taxonomic richness decreased only to a minor extent while proportional changes among dominant taxa are more decisive.

Future developments will probably comprise technical refinements to reduce biases in sedaDNA data, as the relevant sequencing technologies are progressing quickly and sequence databases are continuously enhanced with new genomic reference sequences. Biases currently introduced through the PCR step will potentially be reduced as DNA extracts will increasingly be sequenced directly - all together providing a more comprehensive understanding of past ecosystems.

\section{Data availability}

The paleogenetic and pollen datasets generated and analysed during this study are available at doi:10.1594/PANGAEA.870897 (Zimmermann et al., 2017).

\section{The Supplement related to this article is available online at doi:10.5194/bg-14-575-2017-supplement.}

Author contributions. Heike Hildegard Zimmermann performed the core sub-sampling, the genetic laboratory work and all bioinformatics and statistical analyses, guided by Laura Saskia Epp, Ulrike Herzschuh and Kathleen Rosmarie Stoof-Leichsenring. Elena Raschke counted pollen, spores and algae. Pier Paul Overduin coordinated the field work in 2012 and collected the core. Georg Schwamborn and Lutz Schirrmeister opened the core and advised on sub-sampling. Heike Hildegard Zimmermann wrote the paper that all co-authors commented on.
Competing interests. The authors declare that they have no conflict of interest.

Acknowledgements. We are grateful to the German Federal Ministry of Education and Research (BMBF) for funding this study as part of the joint German-Russian research project CARBOPERM (03G0836B, 03G0836F). We thank our colleagues who helped during fieldwork in 2012 as part of the Russian-German Cooperation SYSTEM LAPTEV SEA. Laura Saskia Epp is supported by the German Research Council (DFG grant EP98/2-1 to Laura Saskia Epp). We gratefully acknowledge Jonas Grünwald, for assistance with the sub-sampling, Daronja Trense, for pollen sample preparation, Liv Heinecke for the age-depth model and Bennet Juhls for compiling the maps. Finally, the paper benefited from English language correction from Cathy Jenks.

The article processing charges for this open-access publication were covered by a Research

Centre of the Helmholtz Association.

Edited by: V. Brovkin

Reviewed by: N. Rudaya, E. Rivkina, and one anonymous referee

\section{References}

Aiken, S. G., Dallwitz, M. J., Consaul, L. L., McJannet, C. L., Boles, R. L., Argus, G. W., Gillett, J. M., Scott, P. J., Elven, R., LeBlanc, M. C., Gillespie, L. J., Brysting, A. K., Solstad, H., and Harris, J. G.: Flora of the Canadian Arctic Archipelago: Descriptions, Illustrations, Identification, and Information Retrieval. NRC Research Press, National Research Council of Canada, Ottawa, available at: http://nature.ca/aaflora/data/index.htm (last access: 20 July 2016), 2007.

Alsos, I. G., Coissac, E., Edwards, M., Foreid, M. K., Gielly, L., Sjoegren, P., Taberlet, P., and Yoccoz, N.: Plant DNA in sediments: to which degree do they represent the flora?, GENOME, 58, p. 186, 2015.

Andreev, A., Schirrmeister, L., Siegert, C., Bobrov, A. A., Demske, D., Seiffert, M., and Hubberten, H. W.: Paleoenvironmental changes in Northeastern Siberia during the Late Quaternary evidence from pollen records of the Bykovsky Peninsula, Polarforschung, 70, 13-25, 2002.

Andreev, A. A., Schirrmeister, L., Tarasov, P. E., Ganopolski, A., Brovkin, V., Siegert, C., Wetterich, S., and Hubberten, H.-W.: Vegetation and climate history in the Laptev Sea region (Arctic Siberia) during Late Quaternary inferred from pollen records, Quaternary Sci. Rev., 30, 2182-2199, doi:10.1016/j.quascirev.2010.12.026, 2011.

Andrews, S.: FastQC: a quality control tool for high throughput sequence data, available at: http://www.bioinformatics.babraham ac.uk/projects/fastqc (last access: 3 February 2017), 2010.

Arnold, L. J., Roberts, R. G., MacPhee, R. D. E., Haile, J. S., Brock, F., Möller, P., Froese, D. G., Tikhonov, A. N., Chivas, A. R., Gilbert, M. T. P., and Willerslev, E.: Paper II - Dirt, dates and DNA: OSL and radiocarbon chronologies of perennially frozen 
sediments in Siberia, and their implications for sedimentary ancient DNA studies, Boreas, 40, 417-445, doi:10.1111/j.15023885.2010.00181.x, 2011.

Bellemain, E., Davey, M. L., Kauserud, H., Epp, L. S., Boessenkool, S., Coissac, E., Geml, J., Edwards, M., Willerslev, E., Gussarova, G., Taberlet, P., and Brochmann, C.: Fungal palaeodiversity revealed using high-throughput metabarcoding of ancient DNA from arctic permafrost, Environ. Microbiol., 15, 11761189, doi:10.1111/1462-2920.12020, 2013.

Bennett, B.: Determination of the number of zones in a biostratigraphical sequence, New Phytol., 132, 155-170, 1996.

Beug, H.-J.: Leitfaden der Pollenbestimmung, Verlag Dr. Friedrich Pfeil, München, 2004.

Binladen, J., Gilbert, M. T. P., Bollback, J. P., Panitz, F., Bendixen, C., Nielsen, R., and Willerslev, E.: The Use of Coded PCR Primers Enables High-Throughput Sequencing of Multiple Homolog Amplification Products by 454 Parallel Sequencing, PLoS ONE, 2, e197, doi:10.1371/journal.pone.0000197, 2007.

Birks, H. H.: Plant macrofossils, in: Tracking Environmental Change Using Lake Sediments, Vol. 3 Terrestrial, Algal, and Siliceous Indicators, edited by: Smol, J. P., Birks, H. J. B., Last, W. M., Bradley, R. S., and Alverson, K., Springer Netherlands, Dordrecht, available at: http://link.springer.com/10.1007/ 0-306-47668-1 (last access: 29 July 2016), 2001.

Blaauw, M. and Christen, J. A.: Flexible paleoclimate age-depth models using an autoregressive gamma process, Bayesian Anal., 6, 457-474, doi:10.1214/ba/1339616472, 2011.

Boessenkool, S., McGlynn, G., Epp, L. S., Taylor, D., Pimentel, M., Gizaw, A., Nemomissa, S., Brochmann, C., and Popp, M.: Use of ancient sedimentary DNA as a novel conservation tool for high-altitude tropical biodiversity, Conserv. Biol., 28, 446-455, doi:10.1111/cobi.12195, 2014.

Boyer, F., Mercier, C., Bonin, A., Le Bras, Y., Taberlet, P., and Coissac, E.: OBITools: a Unix-inspired software package for DNA metabarcoding, Mol. Ecol. Resour., 16, 176-182, doi:10.1111/1755-0998.12428, 2016.

CAVM Team: Circumpolar Arctic Vegetation Map (1:7,500,000 scale), Conservation of Arctic Flora and Fauna (CAFF) Map No. 1, U.S. Fish and Wildlife Service, Anchorage, Alaska, available at: http://www.geobotany.uaf.edu/cavm/ (last access: 3 February 2017), 2003.

Champlot, S., Berthelot, C., Pruvost, M., Bennett, E. A., Grange, T., and Geigl, E.-M.: An efficient multistrategy DNA decontamination procedure of PCR reagents for hypersensitive PCR applications, PLoS ONE, 5, e13042, doi:10.1371/journal.pone.0013042, 2010.

Cornwell, W. K., Cornelissen, J. H. C., Amatangelo, K., Dorrepaal, E., Eviner, V. T., Godoy, O., Hobbie, S. E., Hoorens, B., Kurokawa, H., Pérez-Harguindeguy, N., Quested, H. M., Santiago, L. S., Wardle, D. A., Wright, I. J., Aerts, R., Allison, S. D., Van Bodegom, P., Brovkin, V., Chatain, A., Callaghan, T. V., Díaz, S., Garnier, E., Gurvich, D. E., Kazakou, E., Klein, J. A., Read, J., Reich, P. B., Soudzilovskaia, N. A., Vaieretti, M. V., and Westoby, M.: Plant species traits are the predominant control on litter decomposition rates within biomes worldwide, Ecol. Lett., 11, 1065-1071, doi:10.1111/j.1461-0248.2008.01219.x, 2008.

Cox, P. A.: Hydrophilous pollination, Annu. Rev. Ecol. Syst., 19, 261-279, doi:10.1146/annurev.es.19.110188.001401, 1988.
Czudek, T. and Demek, J.: Thermokarst in Siberia and its influence on the development of lowland relief, Quaternary Res., 1, 103120, doi:10.1016/0033-5894(70)90013-X, 1970.

Davidson, E. A. and Janssens, I. A.: Temperature sensitivity of soil carbon decomposition and feedbacks to climate change, Nature, 440, 165-173, doi:10.1038/nature04514, 2006.

Davidson, E. A., Trumbore, S. E., and Amundson, R.: Biogeochemistry: soil warming and organic carbon content, Nature, 408, 789-790, 2000.

De Barba, M., Miquel, C., Boyer, F., Mercier, C., Rioux, D., Coissac, E., and Taberlet, P.: DNA metabarcoding multiplexing and validation of data accuracy for diet assessment: Application to omnivorous diet, Mol. Ecol. Resour., 14, 306-323, doi:10.1111/1755-0998.12188, 2014.

de Klerk, P., Donner, N., Joosten, H., Karpov, N. S., Minke, M., Seifert, N., and Theuerkauf, M.: Vegetation patterns, recent pollen deposition and distribution of non-pollen palynomorphs in a polygon mire near Chokurdakh (NE Yakutia, NE Siberia), Boreas, 38, 39-58, doi:10.1111/j.15023885.2008.00036.x, 2009.

de Klerk, P., Donner, N., Karpov, N. S., Minke, M., and Joosten, H.: Short-term dynamics of a low-centred ice-wedge polygon near Chokurdakh (NE Yakutia, NE Siberia) and climate change during the last ca 1250 years, Quaternary Sci. Rev., 30, 3013-3031, doi:10.1016/j.quascirev.2011.06.016, 2011.

de Klerk, P., Teltewskoi, A., Theuerkauf, M., and Joosten, H.: Vegetation patterns, pollen deposition and distribution of nonpollen palynomorphs in an ice-wedge polygon near Kytalyk (NE Siberia), with some remarks on Arctic pollen morphology, Polar Biol., 37, 1393-1412, doi:10.1007/s00300-014-1529-3, 2014.

Duchkov, A. D., Zheleznjak, M., and Sokolova, L. S.: Electronic geothermal atlases of Asian Russia, Sciences in Cold and Arid Regions, 6, 479-483, 2014.

Epp, L. S., Boessenkool, S., Bellemain, E. P., Haile, J., Esposito, A., Riaz, T., Erséus, C., Gusarov, V. I., Edwards, M. E., Johnsen, A., Stenøien, H. K., Hassel, K., Kauserud, H., Yoccoz, N. G., Bråthen, K. A., Willerslev, E., Taberlet, P., Coissac, E., and Brochmann, C.: New environmental metabarcodes for analysing soil DNA: potential for studying past and present ecosystems, Mol. Ecol., 21, 1821-1833, doi:10.1111/j.1365294X.2012.05537.x, 2012.

Epp, L. S., Gussarova, G., Boessenkool, S., Olsen, J., Haile, J., Schrøder-Nielsen, A., Ludikova, A., Hassel, K., Stenøien, H. K., Funder, S., Willerslev, E., Kjær, K., and Brochmann, C.: Lake sediment multi-taxon DNA from North Greenland records early post-glacial appearance of vascular plants and accurately tracks environmental changes, Quaternary Sci. Rev., 117, 152163, doi:10.1016/j.quascirev.2015.03.027, 2015.

Faegri, K. and Iversen, J.: Textbook of pollen analysis, 4th Edn., edited by: Faegri, K., Kaland, P. E., and Krzywinski, K., Chichester: John Wiley \& Sons, 328 pp., 1989.

Grimm, E. C.: CONISS: A FORTRAN 77 Program for stratigraphically constrained cluster analysis by the method of incremental sum of squares, Comput. Geosci., 13, 13-35, 1987.

Grosse, G., Schirrmeister, L., Siegert, C., Kunitsky, V. V., Slagoda, E. A., Andreev, A. A., and Dereviagyn, A. Y.: Geological and geomorphological evolution of a sedimentary periglacial landscape in Northeast Siberia during the Late Quaternary, Geomorphology, 86, 25-51, doi:10.1016/j.geomorph.2006.08.005, 2007. 
Grosse, G., Romanovsky, V., Jorgenson, T., Walter Anthony, K., Brown, J., and Overduin, P. P.: Vulnerability and feedbacks of permafrost to climate change, EOS T. Am. Geophys. Un., 92, 73-80, doi:10.1029/2011EO090001, 2011.

Günther, F., Overduin, P. P., Makarov, A. S., and Grigoriev, M. N.: Russian-German cooperation SYSTEM LAPTEV SEA?: the expeditions Laptev Sea - Mamontov Klyk 2011 \& Buor Khaya 2012, Alfred Wegener Institute for Polar and Marine Research, Bremerhaven, 2013a.

Günther, F., Overduin, P. P., Sandakov, A. V., Grosse, G., and Grigoriev, M. N.: Short- and long-term thermo-erosion of ice-rich permafrost coasts in the Laptev Sea region, Biogeosciences, 10, 4297-4318, doi:10.5194/bg-10-4297-2013, 2013b.

Haile, J., Holdaway, R., Oliver, K., Bunce, M., Gilbert, M. T. P., Nielsen, R., Munch, K., Ho, S. Y. W., Shapiro, B., and Willerslev, E.: Ancient DNA chronology within sediment deposits: Are Paleobiological reconstructions possible and is DNA leaching a factor?, Mol. Biol. Evol., 24, 982-989, doi:10.1093/molbev/msm016, 2007.

Haile, J., Froese, D. G., MacPhee, R. D. E., Roberts, R. G., Arnold, L. J., Reyes, A. V., Rasmussen, M., Nielsen, R., Brook, B. W., Robinson, S., Demuro, M., Gilbert, M. T. P., Munch, K., Austin, J. J., Cooper, A., Barnes, I., Möller, P., and Willerslev, E.: Ancient DNA reveals late survival of mammoth and horse in interior Alaska, P. Natl. Acad. Sci. USA, 106, 22352-22357, doi:10.1073/pnas.0912510106, 2009.

Hansen, A. J., Mitchell, D. L., Wiuf, C., Paniker, L., Brand, T. B., Binladen, J., Gilichinsky, D. A., Rønn, R., and Willerslev, E.: Crosslinks rather than strand breaks determine access to ancient DNA sequences from frozen sediments, Genetics, 173, 11751179, doi:10.1534/genetics.106.057349, 2006.

Heck, K. L., van Belle, G., and Simberloff, D.: Explicit calculation of the rarefaction diversity measurement and the determination of sufficient sample size, Ecology, 56, 1459-1461, doi:10.2307/1934716, 1975.

Hobbie, S. E.: Effects of plant species on nutrient cycling, Trend. Ecol. Evol., 7, 336-339, doi:10.1016/0169-5347(92)90126-V, 1992.

Hubberten, H. W., Andreev, A., Astakhov, V. I., Demidov, I., Dowdeswell, J. A., Henriksen, M., Hjort, C., Houmark-Nielsen, M., Jakobsson, M., Kuzmina, S., Larsen, E., Lunkka, J. P., Lyså, A., Mangerud, J., Möller, P., Saarnisto, M., Schirrmeister, L., Sher, A. V., Siegert, C., Siegert, M. J., and Svendsen, J. I.: The periglacial climate and environment in northern Eurasia during the last glaciation, Quaternary Sci. Rev., 23, 1333-1357, doi:10.1016/j.quascirev.2003.12.012, 2004.

Hugelius, G., Strauss, J., Zubrzycki, S., Harden, J. W., Schuur, E. A. G., Ping, C.-L., Schirrmeister, L., Grosse, G., Michaelson, G. J., Koven, C. D., O’Donnell, J. A., Elberling, B., Mishra, U., Camill, P., Yu, Z., Palmtag, J., and Kuhry, P.: Estimated stocks of circumpolar permafrost carbon with quantified uncertainty ranges and identified data gaps, Biogeosciences, 11, 6573-6593, doi:10.5194/bg-11-6573-2014, 2014.

Hurlbert, S. H.: The nonconcept of species diversity: A critique and alternative parameters, Ecology, 52, 577-586, doi:10.2307/1934145, 1971.

Iversen, C. M., Sloan, V. L., Sullivan, P. F., Euskirchen, E. S., McGuire, A. D., Norby, R. J., Walker, A. P., Warren, J. M., and
Wullschleger, S. D.: The unseen iceberg: plant roots in arctic tundra, New Phytol., 205, 34-58, doi:10.1111/nph.13003, 2015.

Jankovská, V. and Komárek, J.: Indicative value ofPediastrum and other coccal green algae in palaeoecology, Folia Geobot., 35, 5982, doi:101007/BF02803087, 2000.

John, D. M., Whitton, B. A., and Brook, A. J. (Eds.): The freshwater algal flora of the British Isles: An identification guide to freshwater and terrestrial algae, Cambridge University Press, Cambridge, 2002.

Jørgensen, T., Haile, J., Möller, P., Andreev, A., Boessenkool, S., Rasmussen, M., Kienast, F., Coissac, E., Taberlet, P., Brochmann, C., Bigelow, N. H., Andersen, K., Orlando, L., Gilbert, M. T. P., and Willerslev, E.: A comparative study of ancient sedimentary DNA, pollen and macrofossils from permafrost sediments of northern Siberia reveals long-term vegetational stability, Mol. Ecol., 21, 1989-2003, doi:10.1111/j.1365294X.2011.05287.x, 2012.

Juggins, S.: rioja: Analysis of Quaternary science data, R package version 0.7-3., available at: https://cran.r-project.org/web/ packages/rioja/index.html (last access: 3 February 2017), 2012.

Kanz, C., Aldebert, P., Althorpe, N., Baker, W., Baldwin, A., Bates, K., Browne, P., van den Broek, A., Castro, M., Cochrane, G., Duggan, K., Eberhardt, R., Faruque, N., Gamble, J., Garcia Diez, F., Harte, N., Kulikova, T., Lin, Q., Lombard, V., Lopez, R., Mancuso, R., McHale, M., Nardone, F., Silventoinen, V., Sobhany, S., Stoehr, P., Tuli, M. A., Tzouvara, K., Vaughan, R., Wu, D., Zhu, W., and Apweiler, R.: The EMBL nucleotide sequence database, Nucleic. Acids Res., 33, 29-33, doi:10.1093/nar/gki098, 2005.

Kienast, F., Siegert, C., Dereviagin, A., and Mai, D. H.: Climatic implications of Late Quaternary plant macrofossil assemblages from the Taymyr Peninsula , Siberia, Glob. Planet. Change, 31, 265-281, 2001.

Kienast, F., Schirrmeister, L., Siegert, C., and Tarasov, P.: Palaeobotanical evidence for warm summers in the East Siberian Arctic during the last cold stage, Quaternary Res., 63, 283-300, doi:10.1016/j.yqres.2005.01.003, 2005.

Kienast, F., Tarasov, P., Schirrmeister, L., Grosse, G., and Andreev, A. A.: Continental climate in the East Siberian Arctic during the last interglacial: Implications from palaeobotanical records, Glob. Planet. Change, 60, 535-562, doi:10.1016/j.gloplacha.2007.07.004, 2008.

Knoblauch, C., Beer, C., Sosnin, A., Wagner, D., and Pfeiffer, E.M.: Predicting long-term carbon mineralization and trace gas production from thawing permafrost of Northeast Siberia, Glob Change Biol., 19, 1160-1172, doi:10.1111/gcb.12116, 2013.

Komárek, J. and Jankovska, V.: Review of the Green Algal GenusPediastrum: implication for Pollen analytical Research, Bibliotheca Phycologica, 108, Berlin-Stuttgart, 2003.

Kupriyanova, L. A. and Alyoshina, L. A.: Pollen and spores of plants in the flora of the European part of the USSR (Vol. 1), Academy of Sciences USSR, Komarov Botanical Institute, Leningrad, 1972.

Kupriyanova, L. A. and Alyoshina, L. A.: Pollen and spores of plants from the flora of European part of USSR, LamiaceaeZygophyllaceae, Academy of Sciences USSR, Komarov Botanical Institute, Leningrad, 1978.

Lachenbruch, A. H.: Mechanics of thermal contraction cracks and ice-wedge polygons in permafrost, Geol. Soc. Am. Spec. Pap., 70, 1-66, doi:10.1130/SPE70-p1, 1962. 
Leffingwell, E. de K.: Ground-ice wedges: The dominant form of ground-ice on the north coast of Alaska, J. Geol., 23, 635-654, 1915.

Levy-Booth, D. J., Campbell, R. G., Gulden, R. H., Hart, M. M., Powell, J. R., Klironomos, J. N., Pauls, K. P., Swanton, C. J., Trevors, J. T., and Dunfield, K. E.: Cycling of extracellular DNA in the soil environment, Soil Biol. Biochem., 39, 2977-2991, doi:10.1016/j.soilbio.2007.06.020, 2007.

Lydolph, M. C., Jacobsen, J., Arctander, P., Gilbert, M. T. P., Gilichinsky, D. A., Hansen, A. J., Willerslev, E., and Lange, L.: Beringian paleoecology inferred from permafrostpreserved fungal DNA, Appl. Environ. Microbiol., 71, 10121017, doi:10.1128/AEM.71.2.1012-1017.2005, 2005.

Lyell, C.: Principles of geology: Being an inquiry how far the former changes of the earth's surface are referable to causes now in operation, Murray, London, 1830.

MacArthur, H.: On the relative abundance of bird species, P. Natl. Acad. Sci. USA, 43, 293-295, 1957.

Mensing, S., Smith, J., Burkle Norman, K., and Allan, M.: Extended drought in the Great Basin of western North America in the last two millennia reconstructed from pollen records, Quaternary Int., 188, 79-89, doi:10.1016/j.quaint.2007.06.009, 2008.

Minke, M., Donner, N., Karpov, N. S., de Klerk, P., and Joosten, H.: Distribution, diversity, development and dynamics of polygon mires: Examples from NE Yakutia (NE Siberia), Peatl. Int., 1, 36-40, 2007.

Minke, M., Donner, N., Karpov, N., de Klerk, P., and Joosten, H.: Patterns in vegetation composition, surface height and thaw depth in polygon mires in the Yakutian Arctic (NE Siberia): a microtopographical characterisation of the active layer, Permafrost Periglac., 20, 357-368, doi:10.1002/ppp.663, 2009.

Mogensen, H. L.: The Hows and Whys of Cytoplasmic Inheritance in Seed Plants, Am. J. Bot., 83, 383-404, doi:10.2307/2446172, 1996.

Moore, P. D., Webb, J. A., and Collison, M. E.: Pollen Analysis, 2nd Edn., Blackwell Scientific Publications, Oxford, UK, 1991.

Niemeyer, B., Klemm, J., Pestryakova, L. A., and Herzschuh, U.: Relative pollen productivity estimates for common taxa of the northern Siberian Arctic, Rev. Palaeobot. Palyno., 221, 71-82, doi:10.1016/j.revpalbo.2015.06.008, 2015.

Oksanen, J., Blanchet, F. G., Kindt, R., Legendre, P., Minchin, P. R., O'Hara, R. B., Simpson, G. L., Solymos, P., Stevens, M. H. H., and Wagner, H.: vegan: Community Ecology Package, R package version 2.0-2., available at: https://cran.r-project.org/ web/packages/vegan/index.html (last access: 3 February 2017), 2011.

Parducci, L., Matetovici, I., Fontana, S. L., Bennett, K. D., Suyama, Y., Haile, J., Kjaer, K. H., Larsen, N. K., Drouzas, A. D., and Willerslev, E.: Molecular- and pollen-based vegetation analysis in lake sediments from central Scandinavia, Mol. Ecol., 22, 3511-3524, doi:10.1111/mec.12298, 2013.

Pedersen, M. W., Ginolhac, A., Orlando, L., Olsen, J., Andersen, K., Holm, J., Funder, S., Willerslev, E., and Kjær, K. H.: A comparative study of ancient environmental DNA to pollen and macrofossils from lake sediments reveals taxonomic overlap and additional plant taxa, Quaternary Sci. Rev., 75, 161-168, doi:10.1016/j.quascirev.2013.06.006, 2013.

Pedersen, M. W., Ruter, A., Schweger, C., Friebe, H., Staff, R. A., Kjeldsen, K. K., Mendoza, M. L. Z., Beaudoin, A. B., Zutter, C.,
Larsen, N. K., Potter, B. A., Nielsen, R., Rainville, R. A., Orlando, L., Meltzer, D. J., Kjær, K. H., and Willerslev, E.: Postglacial viability and colonization in North America's ice-free corridor, Nature, 537, 45-49, 2016.

Preston, C. D. and Croft, J. M.: Aquatic plants in Britain and Ireland: a joint project of the Environment Agency Institute of Terrestrial Ecology and the Joint Nature Conservation Committee, Harley, Colchester, 1997.

Rawlence, N. J., Lowe, D. J., Wood, J. R., Young, J. M., Churchman, G. J., Huang, Y.-T., and Cooper, A.: Using palaeoenvironmental DNA to reconstruct past environments: progress and prospects, J. Quaternary Sci., 29, 610-626, doi:10.1002/jqs.2740, 2014.

R Core Team: R: A language and environment for statistical computing, Vienna, Austria, available at: http://www.r-project.org/ (last access: 3 February 2017), 2014.

Romanovsky, V. E., Drozdov, D. S., Oberman, N. G., Malkova, G. V., Kholodov, A. L., Marchenko, S. S., Moskalenko, N. G., Sergeev, D. O., Ukraintseva, N. G., Abramov, A. A., Gilichinsky, D. A., and Vasiliev, A. A.: Thermal state of permafrost in Russia, Permafrost Periglac., 21, 136-155, doi:10.1002/ppp.683, 2010.

Savelieva, L. A., Raschke, E. A., and Titova, D. V.: Photographic Atlas of Plants and Pollen of the Lena River Delta, St. Petersburg State University, Saint-Petersburg, 2013.

Sayers, E. W., Barrett, T., Benson, D. A., Bryant, S. H., Canese, K., Chetvernin, V., Church, D. M., DiCuccio, M., Edgar, R., Federhen, S., Feolo, M., Geer, L. Y., Helmberg, W., Kapustin, Y., Landsman, D., Lipman, D. J., Madden, T. L., Maglott, D. R., Miller, V., Mizrachi, I., Ostell, J., Pruitt, K. D., Schuler, G. D., Sequeira, E., Sherry, S. T., Shumway, M., Sirotkin, K., Souvorov, A., Starchenko, G., Tatusova, T. A., Wagner, L., Yaschenko, E. and Ye, J.: Database resources of the National Center for Biotechnology Information, Nucleic Acids Res., 37, 5-15, doi:10.1093/nar/gkn741, 2009.

Schirrmeister, L., Grosse, G., Wetterich, S., Overduin, P. P., Strauss, J., Schuur, E. A. G., and Hubberten, H.-W.: Fossil organic matter characteristics in permafrost deposits of the northeast Siberian Arctic, J. Geophys. Res., 116, G00M02, doi:10.1029/2011JG001647, 2011a.

Schirrmeister, L., Kunitsky, V., Grosse, G., Wetterich, S., Meyer, H., Schwamborn, G., Babiy, O., Derevyagin, A., and Siegert, C.: Sedimentary characteristics and origin of the Late Pleistocene Ice Complex on north-east Siberian Arctic coastal lowlands and islands - A review, Quaternary Int., 241, 3-25, doi:10.1016/j.quaint.2010.04.004, 2011 b.

Schirrmeister, L., Schwamborn, G., Overduin, P. P., Strauss, J., Fuchs, M. C., Grigoriev, M., Yakshina, I., Rethemeyer, J., Dietze, E., and Wetterich, S.: Yedoma Ice Complex of the Buor Khaya Peninsula (southern Laptev Sea), Biogeosciences Discuss., doi:10.5194/bg-2016-283, in review, 2016.

Schnell, I. B., Bohmann, K., and Gilbert, M. T. P.: Tag jumps illuminated - reducing sequence-to-sample misidentifications in metabarcoding studies, Mol. Ecol. Resour., 15, 1289-1303, doi:10.1111/1755-0998.12402, 2015.

Sher, A. V., Kuzmina, S. A., Kuznetsova, T. V., and Sulerzhitsky, L. D.: New insights into the Weichselian environment and climate of the East Siberian Arctic, derived from fossil insects, plants, and mammals, Quaternary Sci. Rev., 24, 533-569, doi:10.1016/j.quascirev.2004.09.007, 2005. 
Simpson, G. L.: Analogue methods in palaeoecology: Using the analogue package, J. Stat. Softw., 22, 1-29, doi:10.18637/jss.v022.i02, 2007.

Simpson, G. L. and Oksanen, J.: analogue: Analogue and weighted averaging methods for palaeoecology, available at: http://cran. r-project.org/package=analogue (last access: 3 February 2017), 2016.

Sjögren, P., van der Knaap, W. O., Huusko, A., and van Leeuwen, J. F. N.: Pollen productivity, dispersal, and correction factors for major tree taxa in the Swiss Alps based on pollen-trap results, Rev. Palaeobot. Palynol., 152, 200-210, doi:10.1016/j.revpalbo.2008.05.003, 2008.

Sjögren, P., Edwards, M. E., Gielly, L., Langdon, C. T., Croudace, I. W., Merkel, M. K. F., Fonville, T., and Alsos, I. G.: Lake sedimentary DNA accurately records 20th Century introductions of exotic conifers in Scotland, New Phytol., 213, 929-941, doi:10.1111/nph.14199, 2016.

Soininen, E. M., Gauthier, G., Bilodeau, F., Berteaux, D., Gielly, L., Taberlet, P., GUssarova, G., Bellemain, E., Hassel, K., Stenøien, H. K., Epp, L., Schrøder-Nielsen, A., Brochmann, C., and Yoccoz, N. G.: Highly overlapping winter diet in two sympatric lemming species revealed by DNA metabarcoding, Plos One, 10, e0115335, doi:10.1371/journal.pone.0115335, 2015.

Sokolovskaya, A. P.: Vegetation of Far North and its development, in: Pollen of the Arctic Plants, Komarov Botanical Institute, Academy of Sciences USSR, Moscow-Leningrad, 1958.

Sønstebø, J. H., Gielly, L., Brysting, A. K., Elven, R., Edwards, M., Haile, J., Willerslev, E., Coissac, E., Rioux, D., Sannier, J., Taberlet, P., and Brochmann, C.: Using next-generation sequencing for molecular reconstruction of past Arctic vegetation and climate, Mol. Ecol. Resour., 10, 1009-1018, doi:10.1111/j.17550998.2010.02855.x, 2010.

Stapel, J. G., Schirrmeister, L., Overduin, P. P., Wetterich, S., Strauss, J., Horsfield, B., and Mangelsdorf, K.: Microbial lipid signatures and substrate potential of organic matter in permafrost deposits: Implications for future greenhouse gas production, J. Geophys. Res.-Biogeo., 121, 2652-2666, doi:10.1002/2016JG003483, 2016.

Stockmarr, J.: Tablets with spores used in absolute pollen analysis, Pollen et Spores, 13, 615-621, 1971.

Strauss, J., Schirrmeister, L., Wetterich, S., Borchers, A., and Davydov, S. P.: Grain-size properties and organic-carbon stock of Yedoma Ice Complex permafrost from the Kolyma lowland, northeastern Siberia, Global Biogeochem. Cy., 26, 1-12, doi:10.1029/2011GB004104, 2012.

Strauss, J., Schirrmeister, L., Grosse, G., Wetterich, S., Ulrich, M., Herzschuh, U., and Hubberten, H.-W.: The deep permafrost carbon pool of the Yedoma region in Siberia and Alaska, Geophys. Res. Lett., 40, 6165-6170, doi:10.1002/2013GL058088, 2013.

Strauss, J., Schirrmeister, L., Mangelsdorf, K., Eichhorn, L., Wetterich, S., and Herzschuh, U.: Organic-matter quality of deep permafrost carbon - a study from Arctic Siberia, Biogeosciences, 12, 2227-2245, doi:10.5194/bg-12-2227-2015, 2015.

Taberlet, P., Coissac, E., Pompanon, F., Gielly, L., Miquel, C., Valentini, A., Vermat, T., Corthier, G., Brochmann, C., and Willerslev, E.: Power and limitations of the chloroplast trnL (UAA) intron for plant DNA barcoding, Nucleic Acids Res., 35, e14, doi:10.1093/nar/gk1938, 2007.
Teltewskoi, A., Beermann, F., Beil, I., Bobrov, A., de Klerk, P., Lorenz, S., Lüder, A., Michaelis, D., and Joosten, H.: 4000 years of changing wetness in a permafrost polygon peatland (Kytalyk, NE Siberia): A comparative high-resolution multi-proxy study, Permafrost Periglac., 27, 76-95, doi:10.1002/ppp.1869, 2016.

Thomsen, P. F. and Willerslev, E.: Environmental DNA An emerging tool in conservation for monitoring past and present biodiversity, Biol. Conserv., 183, 4-18, doi:10.1016/j.biocon.2014.11.019, 2015.

van Geel, B.: Non-pollen palynomorphs, in: Tracking environmental change using lake sediments: terrestrial, algal, and siliceous indicators, edited by: Smol, J. P., Birks, H. J. B., Last, W. M., Bradley, R. S., and Alverson, K., 99-119, Springer Netherlands, Dordrecht, doi:10.1007/0-306-47668-1_6, 2001.

van Geel, B. and Aptroot, A.: Fossil ascomycetes in Quaternary deposits, Nova Hedwig., 82, 313-329, doi:10.1127/00295035/2006/0082-0313, 2006.

van Geel, B., Hallewas, D. P., and Pals, J. P.: A late Holocene deposit under the Westfriese Zeedijk near Enkhuizen (Prov. of Noord-Holland, The Netherlands): Palaeoecological and archaeological aspects, Rev. Palaeobot. Palynol., 38, 269-335, doi:10.1016/0034-6667(83)90026-X, 1983.

van der Knaap, W. O.: Transported pollen and spores on Spitsbergen and Jan Mayen, Pollen Spores, 24, 449-453, 1987.

Wagner, D., Gattinger, A., Embacher, A., Pfeiffer, E.-M., Schloter, M., and Lipski, A.: Methanogenic activity and biomass in Holocene permafrost deposits of the Lena Delta, Siberian Arctic and its implication for the global methane budget, Glob. Change Biol., 13, 1089-1099, doi:10.1111/j.1365-2486.2007.01331.x, 2007.

Willerslev, E., Hansen, A. J., Binladen, J., Brand, T. B., Gilbert, M. T. P., Shapiro, B., Bunce, M., Wiuf, C., Gilichinsky, D. A., and Cooper, A.: Diverse Plant and Animal Genetic Records from Holocene and Pleistocene Sediments, Science, 300, 791-795, doi:10.1126/science.1084114, 2003.

Willerslev, E., Hansen, A. J., and Poinar, H. N.: Isolation of nucleic acids and cultures from fossil ice and permafrost, Trends Ecol. Evol., 19, 141-147, doi:10.1016/j.tree.2003.11.010, 2004a.

Willerslev, E., Hansen, A. J., Rønn, R., Brand, T. B., Barnes, I., Wiuf, C., Gilichinsky, D., Mitchell, D., and Cooper, A.: Longterm persistence of bacterial DNA, Curr. Biol., 14, R9-R10, doi:10.1016/j.cub.2003.12.012, 2004b.

Willerslev, E., Davison, J., Moora, M., Zobel, M., Coissac, E., Edwards, M. E., Lorenzen, E. D., Vestergard, M., Gussarova, G., Haile, J., Craine, J., Gielly, L., Boessenkool, S., Epp, L. S., Pearman, P. B., Cheddadi, R., Murray, D., Brathen, K. A., Yoccoz, N., Binney, H., Cruaud, C., Wincker, P., Goslar, T., Alsos, I. G., Bellemain, E., Brysting, A. K., Elven, R., Sonstebo, J. H., Murton, J., Sher, A., Rasmussen, M., Ronn, R., Mourier, T., Cooper, A., Austin, J., Moller, P., Froese, D., Zazula, G., Pompanon, F., Rioux, D., Niderkorn, V., Tikhonov, A., Savvinov, G., Roberts, R. G., MacPhee, R. D. E., Gilbert, M. T. P., Kjaer, K. H., Orlando, L., Brochmann, C., and Taberlet, P.: Fifty thousand years of Arctic vegetation and megafaunal diet, Nature, 506, 47-51, doi:10.1038/nature12921, 2014.

Xie, C.-F. and Lou, H.-X.: Secondary metabolites in bryophytes: An ecological aspect, Chem. Biodivers., 6, 303-312, doi:10.1002/cbdv.200700450, 2009. 
Yoccoz, N. G., Bråthen, K. A., Gielly, L., Haile, J., Edwards, M. E., Goslar, T., Von Stedingk, H., Brysting, A. K., Coissac, E., Pompanon, F., Sønstebø, J. H., Miquel, C., Valentini, A., De Bello, F., Chave, J., Thuiller, W., Wincker, P., Cruaud, C., Gavory, F., Rasmussen, M., Gilbert, M. T. P., Orlando, L., Brochmann, C., Willerslev, E., and Taberlet, P.: DNA from soil mirrors plant taxonomic and growth form diversity, Mol. Ecol., 21, 3647-3655, doi:10.1111/j.1365-294X.2012.05545.x, 2012.

Zibulski, R., Herzschuh, U., Pestryakova, L. A., Wolter, J., Müller, S., Schilling, N., Wetterich, S., Schirrmeister, L., and Tian, F.: River flooding as a driver of polygon dynamics: modern vegetation data and a millennial peat record from the Anabar River lowlands (Arctic Siberia), Biogeosciences, 10, 5703-5728, doi:10.5194/bg-10-5703-2013, 2013.
Zibulski, R., Herzschuh, U., and Pestryakova, L. A.: Vegetation patterns along micro-relief and vegetation type transects in polygonal landscapes of the Siberian Arctic, J. Veg. Sci., 27, 377-386, doi:10.1111/jvs.12356, 2016.

Zimmermann, H. H., Raschke, E., Epp, L. S., Stoof-Leichsenring, K. R., Schwamborn, G., Schirrmeister, L., Overduin, P. P., and Herzschuh, U.: Pollen profile of sediment core BK-8, Dataset \#870897, doi:10.1594/PANGAEA.870897, 2017. 